\title{
1. INTRODUCTION AND SUMMARY OF RESULTS FROM DSDP LEG 55, THE HAWAIIAN-EMPEROR HOT-SPOT EXPERIMENT
}

\author{
Everett D. Jackson, ${ }^{, 1}$ Itaru Koizumi, ${ }^{2}$ G. Brent Dalrymple, ${ }^{1}$ \\ David A. Clague,${ }^{3}$ R. James Kirkpatrick, ${ }^{4}$ and H. Gary Greene ${ }^{1}$
}

\section{INTRODUCTION}

The Hawaiian Islands, the seamounts on the Hawaiian Ridge, and The Emperor Seamounts are part of the Hawaiian-Emperor chain, a quasilinear array of Cenozoic shield volcanoes that stretches nearly 6000 kilometers across the floor of the Pacific (Figure 1, in pocket). This unusual geologic feature comprises some 107 individual volcanoes that represent more than $740 \times 10^{3}$ $\mathrm{km}^{3}$ of lava (Bargar and Jackson, 1974).

At the southeast end of the chain lie the eight principal Hawaiian Islands, which have been the subject of scientific study since first described by the missionaries William Ellis and Joseph Goodrich in 1825-26 (Macdonald, 1976). The Island of Hawaii includes the chain's only active volcanoes, Mauna Loa and Kilauea, although both Hualalai volcano on Hawaii and Haleakala volcano on Maui have erupted in historic times. Between Kure and Niihau only a few of the volcanoes rise above the sea as small volcanic islets and atolls. Beyond Kure the volcanoes in the chain are entirely submerged beneath the sea. Approximately 3500 kilometers northwest of Hawaii, the Hawaiian chain bends sharply to the north and becomes the Emperor Seamounts, which continue northward $2300 \mathrm{~km}$ and disappear near the intersection of the Kurile and Aleutian trenches (Figure 1, in pocket).

The volcanoes of the Hawaiian-Emperor chain were erupted onto the floor of the Pacific Ocean apparently without regard to the age or pre-existing structure of the oceanic crust. The age of the sea floor beneath the Hawaiian-Emperor volcanoes is poorly known because of the paucity of marine magnetic anomalies in the central Pacific, but the crust is known to be primarily Upper Cretaceous and older (Hilde et al., 1976). In addition, the chain cuts obliquely across the trend of both magnetic anomalies and transform faults. Several major fracture zones actually cross the chain without detec-

\footnotetext{
*Everett Dale Jackson died on July 28, 1978, before this manuscript was written. He was a Co-Chief Scientist on Leg 55 as well as the principal author of the proposal that resulted in drilling in the Emperor Seamounts, and many of the results discussed herein are due either directly or indirectly to his leadership and imagination. It is appropriate, therefore, that he appear as senior author of this paper even though fate prevented him from actually writing the words.

${ }^{1}$ Geological Survey, Menlo Park, California, USA.

2 Osaka University, Osaka, Japan.

${ }^{3}$ Middlebury College, Middlebury, Vermont, USA.

4 University of Illinois, Urbana, Illinois, USA.
}

tably affecting the trend of the shield volcanoes, even though these same fracture zones offset magnetic anomalies to the east by as much as $800 \mathrm{~km}$ (Jackson et al., 1972). Thus, the position of the chain appears to be independent of the structure of the older sea floor on which it developed.

It is now thought that the Hawaiian-Emperor chain formed during the last $70 \mathrm{~m} . \mathrm{y}$. as the Pacific lithospheric plate moved north then west relative to a melting anomaly, the Hawaiian hot spot, ${ }^{5}$ located in the asthenosphere. According to the hot-spot hypothesis, a trail of volcanoes was left on the ocean floor as each volcano was progressively cut off from its source of lava and a new volcano was born behind it. If this hypothesis is correct, then the Hawaiian-Emperor bend represents a major change in the motion of the Pacific plate relative to the Hawaiian hot spot.

Wilson $(1963 \mathrm{a}, 1963 \mathrm{~b})$ was first to propose that the Hawaiian Islands and other parallel, northwest-southeast island chains in the Pacific were formed by spreading of the sea floor over sources of lava in the asthenosphere. He suggested that these sources might be located in the stable cores of mantle convection cells, thus implying that they are relatively fixed with respect to the spin axis. Although Wilson confined his hypothesis to the volcanoes of the Hawaiian Islands and along the Hawaiian Ridge, the Emperor chain was recognized as a northward continuation of the Hawaiian chain by Bezrukov and Udincev (1955) shortly after the Emperor Seamounts were first described by Tayama (1952) and Dietz (1954). The term "hot spot" was coined by Christofferson (1968), who extended Wilson's idea to include the Emperor Seamounts and suggested that the Hawaiian-Emperor bend represents a major change in the direction of sea-floor spreading from northward to westward.

The hot-spot hypothesis was more fully developed by Morgan (1972a, 1972b), who proposed that hot spots were thermal plumes of material rising from the deep mantle. According to Morgan, these plumes not only supply both heat and magma to form the volcanoes, but also provide the driving forces for plate motions. $\mathrm{He}$ suggested that four parallel island seamount chains in the Pacific - the Hawaiian-Emperor, Tuamoto-Line Islands, Austral-Marshalls, and Pratt-Welker chains -

\footnotetext{
${ }^{5}$ The term hot spot is commonly used to describe the Hawaiian and other melting anomalies. In its generic sense, as used here, it implies neither mechanism nor excess heat.
} 
were generated by motion of the Pacific plate over four hot spots in the mantle that are fixed relative to each other and thus provide a stationary reference frame for plate motion analyses.

In addition to thermal plumes, a variety of models have been proposed for the Hawaiian hot-spot mechanism. These include a propagating fracture (Betz and Hess, 1942; Jackson and Wright, 1970), diapiric upwelling along a line of structural weakness (Green, 1971: McDougall, 1971), shear melting coupled with thermal feedback (Shaw, 1973) and possibly stabilized by gravitational downwelling of melting residua (Shaw and Jackson, 1973), extrusion induced by lateral motion along the structural boundary between two lithospheric plates (Handschumacher, 1973), and chemical plumes of gravitationally unstable, primordial material rising from the deep mantle (Anderson, 1975). Although most of these models are generally consistent with the observed geometry and kinematics of the Hawaiian-Emperor chain, none adequately explains the chemistry, timing, and sequence of rock types observed in Hawaiian volcanoes. Because the hot-spot mechanism operates in the lower lithosphere or mantle, it may not be observed directly. As a result, no experiment capable of testing the validity of any of the proposed models has yet been developed. The results of a seismic experiment designed to detect a thermal plume beneath Hawaii (Kanasewich et al., 1972, 1973; Davies and Sheppard, 1972) have been shown to be ambiguous (Green, 1975).

Mechanism aside, the kinematic aspects of the hotspot hypothesis and several of its corollaries are subject to test, and have been the object of considerable experimental attention since Wilson (1963) first proposed his imaginative hypothesis. There is little doubt that Hawaiian volcanoes are the best studied in the world. Figure 1 (in pocket) shows the availability of much of the data from both the Hawaiian and Emperor chains. Before 1977, there were enough data from the Hawaiian Islands, the western Hawaiian Ridge, and the Hawaiian-Emperor bend to show that the hot-spot hypothesis provided an acceptable explanation for the origin of the Hawaiian segment of the chain. Data from the Emperor Seamounts, however, were so sparse that the hypothesis could only be tentatively applied to the Emperor segment.

Whereas reasonably adequate data had been obtained for the Hawaiian part of the chain by shorebased sampling and conventional oceanographic techniques, we considered it essential that the experiment be extended to the Emperor Seamounts by drilling with the Glomar Challenger. The principal reasons were (1) that dredging in the central and northern Emperor Seamounts had been unsuccessful because the seamounts north of about $40^{\circ} \mathrm{N}$ latitude are covered by a blanket of ice-rafted glacial sediment; (2) that drilling was the only way of determining the stratigraphic sequence of lava types for comparison with the known eruption sequence of Hawaiian volcanoes; and (3) that samples of known orientation, obtainable only by drilling, were required to determine the paleolatitude of formation of at least one of the Emperor volcanoes as a test of hot-spot fixity.
In addition, seismic and other evidence (Davies et al., 1972; Larson, Moberly, et al., 1975; Greene et al., 1978) indicated that most of the major seamounts in the Emperor chain were capped by organic carbonate reefs or banks. This implied that the volcanoes had had a shallow-water or subaerial history, and that they had undergone substantial subsidence since their extinction. Continuous coring was the only way that the post-eruption history of these volcanoes could be determined.

\section{BACKGROUND AND OBJECTIVES}

Leg 55 was conceived as part of the decade-long experiment to test the kinematic hot-spot hypothesis and several of its more imporant corollaries for the origin of the Hawaiian-Emperor chain. Also of particular importance was the question of whether the Hawaiian hot spot has remained fixed in the mantle. In addition to obtaining data relevant to the hot-spot experiment, we hoped that the drilling would permit us to establish the Cenozoic biostratigraphic zonation for sediments atop the seamounts and better understand the Neogene environment of the central north Pacific. The specific primary objectives of Leg 55, discussed more fully in what follows, were to determine (1) whether the known increase in the age of the volcanoes on the Hawaiian chain with distance from Kilauea continues northward along the Emperor Seamounts; (2) whether the lavas of the Emperor volcanoes are of the same chemical composition and were erupted in the same sequence as those of Hawaiian volcanoes; (3) the latitude of formation of Suiko Seamount as a test of hot-spot fixity; and (4) whether the Emperor Seamounts were once islands and, if so, to determine their post-volcanic and subsidence history.

\section{Age of the Volcanoes}

An important corollary of the kinematic hot-spot hypothesis is that the volcanoes in the HawaiianEmperor chain increase in age with distance from the current location of the hot spot beneath the active volcanoes of Kilauea and Mauna Loa on the Island of Hawaii. Although the increase in age with distance need not be linear to satisfy the hypothesis, this corollary should generally hold true regardless of the hot-spot mechanism or whether the hot spot is fixed or moving.

It has long been known from geomorphic evidence (Dana, 1849, 1890; Stearns, 1946, 1966) that the volcanoes of the Hawaiian Islands become generally older to the northwest away from Kilauea and Mauna Loa. This order of extinction was first quantitatively confirmed by McDougall (1963, 1964), who determined $\mathrm{K}-\mathrm{Ar}$ ages on lavas from Kauai, Oahu, Molokai, Maui, and Hawaii. McDougall's data and data from subsequent $\mathrm{K}-\mathrm{Ar}$ studies of volcanic rocks from the main Hawaiian Islands (Funkhouser, 1968; McDougall, 1969; Dalrymple, 1971; McDougall and Swanson, 1972; Doell and Dalrymple, 1973; Bonhommet et al., 1977; Porter et al., 1977), the Leeward Hawaiian Islands (Dalrymple et al., 1974; 1977), the Western Hawaiian Ridge (Clague et al., 1975), and the southernmost Emperor Seamounts (Clague and Dalrymple, 1973; Clague et al., 1975; Dalrymple and Clague, 1976) have confirmed the hot- 
spot prediction, and have shown that the age progression $^{6}$ is approximately linear from Kilauea through Kauai (5 to 6 m.y.) and Midway ( 28 m.y.) to the Hawaiian-Emperor bend (43 m.y.) and as far as Kōkō Seamount (48 m.y.) $200 \mathrm{~km}$ north of the bend. Paleontologic data on the ages of the volcanoes west of Kauai are sparse, but the available fossil ages from Midway Islands (Cole, 1969; Todd and Low, 1970), DSDP Site 311 west of Midway (Bukry, 1975), Kammu Seamount on the bend (N. Sachs, quoted in Clague and Jarrard, 1973), and Kōkō Seamount (Bukry, 1975) are consistent with the radiometric ages.

Before 1978, radiometric data from volcanoes north of the bend were few and largely unsubstantiated. They consisted of a ${ }^{40} \mathrm{Ar} /{ }^{39} \mathrm{Ar}$ age of $59.6 \mathrm{~m}$.y. on a dredged sample of altered mugearite from Suiko Seamount (Saito and Ozima, 1975, 1977), and conventional K-Ar ages ranging from 22 to $43 \mathrm{~m} . \mathrm{y}$. on dredged andesite and basalt, also from Suiko, that are not only altered but are probably ice-rafted (Ozima et al., 1970). Meiji Seamount, which may be the oldest volcanic edifice in the Emperor chain but also may not be an Emperor volcano at all (Jackson et al., 1972), has a minimum fossil age of about $72 \pm 3$ m.y. (Worsley, 1973; Scholl and Creager, 1973). The lack of reliable age data for the northern and central Emperor Seamounts made it impossible to determine the southward rate of volcanic propagation or even to verify that the volcanoes in the chain increase in age north of Kōko Seamount, as predicted by Morgan (1972a). Thus, before Leg 55, a major corollary of the hot-spot hypothesis remained untested.

One of the primary objectives of Leg 55 was to obtain samples of basalt for $\mathrm{K}-\mathrm{Ar}$ dating and samples of the overlying sediments to determine, by paleontologic methods, the minimum age of cessation of volcanism.

\section{Chemical Composition and Eruptive Sequence}

If the volcanoes of the Hawaiian-Emperor chain were fed from a single melting anomaly, then their lavas should be chemically similar, or at least should have evolved in a systematic way. The voluminous data from the principal Hawaiian Islands (e.g., Macdonald and Katsura, 1964; Macdonald, 1968; Wright, 1971; Beeson, 1976) provide an extensive base with which to compare chemical data from lavas elsewhere in the chain. Chemical studies on samples from the central and eastern Hawaiian ridge (Macdonald, 1969; Dalrymple et al., 1974; Clague, 1974) have shown that the lavas erupted from these volcanoes have remained chemically similar for nearly 50 m.y. North of Kōkō Seamount, pre-Leg 55 data on the chemical composition of the Emperor volcanoes are virtually nonexistent. Such data are necessary to test the various mechanisms proposed for hot spots, and to provide petrochemical boundary conditions for the development and refinement of hot-spot models.

\footnotetext{
${ }^{6}$ All K-Ar ages referenced to the older literature have been converted to the new IUGS constants (Steiger and Jager, 1977).
}

As important as the chemical composition of lavas in Hawaiian-Emperor volcanoes is the sequence in which the rock types occur. It is known that Hawaiian volcanoes erupt lavas of different and distinct chemical compositions during their evolution and growth (Macdonald and Katsura, 1964; Macdonald, 1968). Most ( 99\%) of an individual Hawaiian volcano is constructed from tholeiitic basalt flows, which erupt rapidly and in copious amounts, building the main shield within only $10^{6}$ years or so (Jackson et al., 1972). Hawaiian tholeiitic flows are chemically distinct from those that form the Pacific sea floor. The tholeiitic shield-building stage is quickly followed by caldera collapse and the calderafilling stage, during which the volcano may erupt both tholeiitic and alkalic lavas. During the post-caldera stage, a relatively thin cap of alkalic basalts and associated differentiated lavas, principally hawaiites, cover the main shield. These account for only one per cent or less of the volume of the volcano. Finally, after a few million years of quiescence and erosion, minor amounts (less than $0.1 \%$ ) of lavas of the nephelinic (post-erosional) suite may be erupted from satellite vents. Although an individual volcano may become extinct before the eruptive cycle is complete, this general sequence appears to be typical for Hawaiian volcanoes. West of Kauai, the basalt lithostratigraphy has been tested only at Midway, where drilling recovered pebbles of the alkalic suite overlying numerous flows of tholeiitic basalt (Macdonald, 1969; Dalrymple et al., 1977). Before Leg 55 there was no basalt lithostratigraphic information from west and north of Midway. The two DSDP holes drilled on Kōkō Seamount (Larson, Moberly, et al., 1975) did not reach volcanic rock, and the basalts recovered from the hole at Meiji Seamount (Creager, Scholl, et al., 1973) are so altered that their identification as either tholeiitic or alkalic is uncertain, although they are probably tholeiitic (Dalrymple, Lanphere, and Natland, this volume).

The major petrologic objectives of Leg 55, then, were to recover basalt samples for petrographic, chemical, and isotopic comparisons with the well-studied Hawaiian volcanoes, to determine whether the basalt types of the Emperor volcanoes were erupted in the same sequence as those in Hawaii, and to determine the longterm chemical behavior of the source responsible for the Hawaiian hot spot.

\section{Hawaiian Hot Spot Fixity}

During the last few years, several studies have tested Morgan's hypothesis that hot spots are fixed in the mantle and provide a stable reference frame for plate motion analyses. Clague and Jarrard (1973) and Jarrard and Clague (1977) examined linear chains in the Pacific and compared the predicted plate motion with equatorial sedimentation patterns (Winterer, 1973) and paleomagnetic data. They concluded that the available data were consistent with the Pacific hot spots being fixed both with respect to one another and with respect to the earth's spin axis. Molnar and Atwater (1973), using plate reconstructions at 21 and $38 \mathrm{~m}$.y. ago, concluded that 
some of the proposed hot spots, particularly Iceland and Hawaii, appeared to have moved several degrees with respect to one another during the last 38 m.y. Minster et al. (1974), Chase (1978), and Minster and Jordan (1978) have numerically modeled the present-day plate motion vectors on a worldwide basis and concluded that there is no reason to suspect that hot spots have moved with respect to one another during the last $10 \mathrm{~m} . \mathrm{y}$.

A corollary of the fixed hot-spot hypothesis is that all the volcanoes in the Hawaiian-Emperor chain formed at the same latitude and longitude. This prediction can be tested by paleomagnetic methods, but before Leg 55 suitable rocks were available from only two of the volcanoes in the Hawaiian-Emperor chain. A paleomagnetic study of basalt cores obtained from two drill holes on Midway Atoll (Ladd et al., 1970) was made by Grommé and Vine (1972). They found a paleolatitude for Midway of $15^{\circ} \pm 4^{\circ}$, which is significantly south of its present latitude of $28^{\circ} \mathrm{N}$ but not statistically different from the present latitude of Hawaii $\left(19.5^{\circ} \mathrm{N}\right)$. A similar result was found by Marshall (1978), who determined a paleolatitude for Meiji Seamount of $19^{\circ} \pm 4^{\circ}$ using basalt samples recovered from DSDP Hole 192A. Although these paleomagnetic data are consistent with the existence of a fixed hot spot, they are somewhat inconclusive because the small number of flows available for both studies makes it uncertain that secular variation was adequately averaged out.

Kodama et al. (1978), using topographic and magnetic data from a detailed survey, have calculated a paleolatitude of $17^{\circ} \pm 5^{\circ}$ for Suiko Seamount. This result is consistent with a fixed Hawaiian hot spot, but a recent similar analysis for Mt. Shasta, a California Quaternary volcano, gave an erroneous result. Blakely and Christiansen (1978) found a magnetic inclination for Mt. Shasta corresponding to a virtual geomagnetic latitude that is $15^{\circ}$ south of the actual latitude of the volcano, and cautioned that magnetic survey data do not always result in reliable paleoinclinations.

One of the principal objectives of Leg 55 was to sample, for paleomagnetic study, a sufficient number of lava flows so that a reliable paleolatitude could be determined for at least one of the volcanoes in the Emperor chain. The multiple re-entry hole at Suiko was specifically designed for this purpose. It was also hoped that fossils in the shallow-water carbonate sediments atop the seamounts, whose existence was predicted by Greene et al. (1978) on the basis of seismic evidence, would provide additional indication of the latitude of formation of the volcanoes.

\section{Post-Volcanic History}

Seismic reflection profiles and previous drilling show that the principal guyots in the central and southern Emperor Seamounts as far north as latitude $45^{\circ} 30^{\prime} \mathrm{N}$ may be capped by ancient coral reefs or carbonate banks (Davies et al., 1972; Larson, Moberly, et al., 1975; Greene et al., 1978; Dalrymple et al., this volume). Although these results strongly suggest a northward component of movement of the Pacific plate, they also imply that most of the Emperor volcanoes once stood above the sea as islands. The Leg 55 drilling was designed partly to determine whether these volcanoes were islands and to establish their post-volcanic and subsidence history.

The drilling into shallow-water carbonate debris was also expected to provide information on the vertical motion of the Pacific plate (Ladd et al., 1970). Previous experience in atoll drilling established without doubt that atolls in the open sea serve as measuring rods for both local and regional changes in the height of sea level relative to seamounts (Ladd et al., 1970; Schlanger and Gillett, 1976). Darwinian subsidence has been qualitatively proven by atoll drilling, although the morphological development of subsiding reefs appears more complex than originally envisioned (Purdy, 1974). Thermal contraction of the aging plate as it moves away from the active ridge is one contributing mechanism (Sclater et al., 1971; Parsons and Sclater, 1977); lithospheric thinning directly beneath the growing volcanoes is another (Detrick and Crough, 1978). These mechanisms, however, fail to account for the emergence recorded at many atolls and volcanic islands. Emergence may result from mid-plate tectonic uplifts (Hsü and Schlanger, 1968; Menard, 1973), from eustatic lowerings of sea level (Stearns, 1974, 1978), or from both (Schlanger and Douglas, 1974). Local tectonic effects, such as flexure caused by loading of the crust by adjacent volcanoes (McNutt and Menard, 1978), may also play a significant role. We purposely located several of the Emperor drill sites in sediment ponds believed to contain shallowwater carbonate material. We hoped that the fossil assemblages in these sediments would provide information about the age and rates of subsidence, and the history of formation of the seamounts. We also thought that data recovered from Emperor sediment ponds might correlate with existing data on the subsidence and emergence of other atolls, and extend the record of these events to a previously unexplored part of the Pacific basin.

\section{Biostratigraphy and Paleoceanography}

Sites drilled on Leg 55 were expected to yield planktonic assemblages that could be correlated with biostratigraphic reference sections from DSDP sites in the North Pacific and from land around the North Pacific. The seamount tops are, for the most part, above the carbonate compensation depth (CCD). Any migration of planktonic assemblages induced by climate will help in correlation of biologic indicators, and in clarification of the history of planktonic communities and paleotemperatures in the northwest Pacific.

\section{OPERATIONAL SUMMARY}

Leg 55 consisted of three phases: (1) shipyard and drydock port call at Bethlehem Steel Company Shipyard, Terminal Island, Los Angeles, California; (2) deadhead steaming from Los Angeles to Honolulu, Hawaii, for a port call and crew change; and (3) scientific phase to investigate the Emperor Seamount chain.

On June 18, 1977, the Glomar Challenger arrived at the Bethlehem Steel Company Shipyard; the leg termi- 
nated 80.0 days later on September 6, 1977, at Yokohama, Japan. The voyage comprised 24.3 days in the shipyard, 1.0 day in port calls at Honolulu and Adak, 36.3 days cruising, and 18.5 days on site. The Challenger travelled 7863 nautical miles and drilled 11 holes at 4 sites. Water depths on site were relatively shallow, and ranged from 1320 to 1874 meters. A total of 797.5 meters of coring resulted in 406.4 meters of core for 51.0 per cent recovery (Table 1 ).

Drill string failures complicated operations during the early part of the leg. On Holes 431, 431A, and 432, the bottom sub on the lower bumper sub failed as a result of bending. All three failures occurred within 30 meters of the mudline while there was no rotation of the drill string. The formation at all three holes was relatively firm, and circulation was required for penetration. The subs failed because of a reduced threaded section in the bottom sub.

At Hole 432A, a different type of failure occurred; the upper service break of the lowermost bumper sub failed while working stuck pipe. Between Sites 432 and 433, the Glomar Challenger proceeded to Adak Island, Alaska, to pick up replacement subs.

Plugging of the bit by pieces of core was a problem on all holes drilled. On Hole 433B and Hole 433C the inner barrel was not latching correctly. It appeared to become unlatched while drilling the hard basalt. The larger inner diameter sleeve is evidently not suitable when drilling hard basalt. No problems were experi- enced while drilling sediments. The re-entries on Site 433 were achieved without major difficulties.

\section{DRILLING RESULTS}

The Glomar Challenger departed Honolulu, Hawaii on 23 July 1977, drilled 11 holes at 4 sites in the Emperor Seamount chain, including a multiple re-entry hole on Suiko Seamount, and arrived at Yokohama, Japan on 6 September 1977. The drill site locations are shown in Figure 2, the coring summary in Table 1, and stratigraphic columns in Figure 3.

\section{Site 430: Ōjin Seamount}

Three holes were drilled at Site 430 in what appeared from seismic records to be a lagoonal sediment pond. We recovered 14 meters of pebbly mudstone that contain a variety of clasts including siltstone and basalt, and shallow-water fossils with upper Eocene calcareous nannofossils. The hole was abandoned because of caving. Hole $430 \mathrm{~A}$ was offset 914 meters $040^{\circ}$ from Hole 430 , and penetrated 118.0 meters of volcaniclastic sand and ash, and basalt. Five flows of basalt were drilled in the interval 59.3 to 118.0 meters, immediately beneath the volcaniclastic sands. The upper four flows are hawaiites; the lower flow unit is a tholeiitic basalt with a composition in the range of known Hawaiian tholeiites. Carbonate sediments above the basalt contain upper Paleocene foraminifers and upper Paleocene nannofossils, as well as benthic foraminifers, ostracodes, bryo-

TABLE 1

Leg 55 Coring Summary

\begin{tabular}{|c|c|c|c|c|c|c|c|c|c|}
\hline Hole & $\begin{array}{c}\text { Dates } \\
\text { (GMT 1977) }\end{array}$ & $\begin{array}{l}\text { Latitude } \\
\text { Longitude }\end{array}$ & $\begin{array}{l}\text { Water } \\
\text { Depth } \\
(\mathrm{m})\end{array}$ & $\begin{array}{l}\text { Total } \\
\text { Penetration } \\
\text { (m) }\end{array}$ & $\begin{array}{l}\text { Basement } \\
\text { Penetration } \\
\text { (m) }\end{array}$ & $\begin{array}{l}\text { No, of } \\
\text { Cores }\end{array}$ & $\begin{array}{l}\text { Meters } \\
\text { Cored }\end{array}$ & $\begin{array}{c}\text { Meters } \\
\text { Recovered }\end{array}$ & $\begin{array}{c}\text { Recovery } \\
(\%)\end{array}$ \\
\hline 430 & August 1 & $\begin{array}{r}37^{\circ} 58.88^{\prime} \mathrm{N} \\
170^{\circ} 35.45^{\prime} \mathrm{E}\end{array}$ & 1464.0 & 14.0 & 0.0 & 3 & 14.0 & 7.90 & 56.4 \\
\hline $430 \mathrm{~A}$ & August 1-2 & $\begin{array}{r}37^{\circ} 59.29^{\prime} \mathrm{N} \\
170^{\circ} 35.86^{\prime} \mathrm{E}\end{array}$ & 1485.5 & 118.0 & 58.7 & 11 & 85.5 & 16.83 & 19.7 \\
\hline $430 \mathrm{~B}$ & August 3 & $\begin{array}{r}37^{\circ} 59.52^{\prime} \mathrm{N} \\
170^{\circ} 36.12^{\prime} \mathrm{E}\end{array}$ & 1492.0 & 3.0 & 0.0 & 1 & 3.0 & 0.10 & 3.0 \\
\hline 431 & August 5 & $\begin{array}{r}42^{\circ} 25.44^{\prime} \mathrm{N} \\
170^{\circ} 32.68^{\prime} \mathrm{E}\end{array}$ & 1714.5 & 9.5 & 0.0 & 2 & 9.5 & 3.33 & 35.1 \\
\hline $431 \mathrm{~A}$ & August 5-6 & $\begin{array}{r}42^{\circ} 25.39^{\prime} \mathrm{N} \\
170^{\circ} 32.60^{\prime} \mathrm{E}\end{array}$ & 1713.5 & 17.0 & 0.0 & 2 & 17.0 & 4.35 & 25.6 \\
\hline 432 & August 6-7 & $\begin{array}{r}41^{\circ} 20.03^{\prime} \mathrm{N} \\
170^{\circ} 22.74^{\prime} \mathrm{E}\end{array}$ & 1320.0 & 17.5 & 0.0 & 1 & 5.5 & 3.00 & 54.5 \\
\hline $432 \mathrm{~A}$ & August 7-8 & $\begin{array}{r}41^{\circ} 20.03^{\prime} \mathrm{N} \\
170^{\circ} 22.74^{\prime} \mathrm{E}\end{array}$ & 1320.0 & 74.0 & 31.9 & 5 & 38.0 & 15.92 & 42.4 \\
\hline 433 & August 16 & $\begin{array}{r}44^{\circ} 46.60^{\prime} \mathrm{N} \\
170^{\circ} 01.26^{\prime} \mathrm{E}\end{array}$ & 1874.0 & 45.0 & 0.0 & 1 & 5.5 & 5.50 & 100.0 \\
\hline $433 \mathrm{~A}$ & August 16-17 & $\begin{array}{r}44^{\circ} 46.60^{\prime} \mathrm{N} \\
170^{\circ} 01.26^{\prime} \mathrm{E}\end{array}$ & 1874.0 & 174.0 & 10.5 & 21 & 174.0 & 88.59 & 50.9 \\
\hline $433 \mathrm{~B}$ & August 18 & $\begin{array}{r}44^{\circ} 46.63^{\prime} \mathrm{N} \\
170^{\circ} 01.23^{\prime} \mathrm{E}\end{array}$ & 1874.0 & 186.5 & 23.0 & 7 & 58.0 & 10.72 & 18.5 \\
\hline \multirow[t]{2}{*}{$433 \mathrm{C}$} & August 18-29 & $\begin{array}{r}44^{\circ} 46.63^{\prime} \mathrm{N} \\
170^{\circ} 01.23^{\prime} \mathrm{E}\end{array}$ & 1874.0 & 550.5 & 387.5 & 50 & 387.5 & 250.15 & 64.6 \\
\hline & & & Totals & 1209.0 & 511.6 & 104 & 797.5 & 406.39 & 51.0 \\
\hline
\end{tabular}




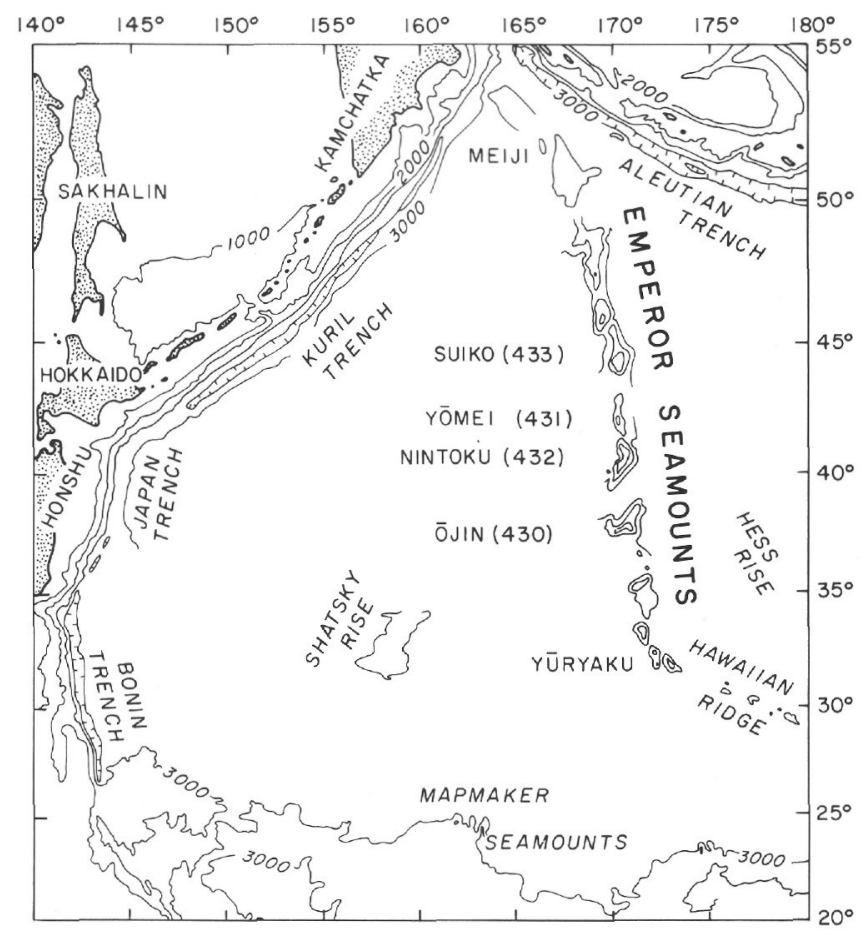

Figure 2. Locations of DSDP Leg 55 sites in the Emperor Seamounts.

zoans, echinoderms, bivalves, and calcareous algae typical of shallow-water carbonate reef or bank environments. Both sediments and fossils indicate that Ōjin Seamount was capped by organic reefs or banks in $\mathrm{Pa}-$ leocene to Eocene time, and that lagoonal deposits are present there, as previously predicted from seismic evidence. Upper Paleocene fossils above the basalt demonstrate that Ōjin Seamount is older than Kōkō Seamount, where lower Eocene fossils were found on Leg 32 (Bukry, 1975). The discovery of both hawaiite and tholeiitic basalt shows that Ojin Volcano is of the Hawaiian type, and probably was constructed by a sequence of eruptive stages typical of Hawaiian volcanoes. The upper four flow units are massive, with coarse vesicular tops, partly oxidized in places, and were clearly erupted subaerially. No pillow structures or any other features suggestive of underwater eruption are present. In addition, part of a red oxidized soil zone, which could only have formed subaerially, was recovered between Flow Units 3 and 4. Natural remanent magnetization in both the volcaniclastic sand and the basalts is stable. The inclinations in the upper four flow units are very similar, however, and suggest that these flows erupted within a very short time. Hole 430B was offset 500 meters $040^{\circ}$ from Hole $430 \mathrm{~A}$ and spudded in an attempt to punch a surface core. The drill bit, however, was completely blocked by basalt fragments, and only about $10 \mathrm{~cm}$ of watery ooze was obtained. The fossils in this ooze are Quaternary; fossils representing the Pliocene through Eocene interval appear to be completely absent at this site, as at Kōkō Seamount, (Larson, Moberly, et al., 1975).

\section{Site 431: Yōmei Seamount}

Two holes were drilled at this site, in what appeared from seismic records to be a faulted terrace. Neither hole reached basalt. In Hole 431, the interval between 0 and 9.5 meters was cored twice, and a total of 3.33 meters of sand and centimeter-sized unconsolidated gravel was recovered. The sediment is composed of 90 per cent angular iron-manganese oxide fragments and 10 per cent rounded pebbles, sponge fragments, foraminifers, and authigenic clay and zeolites. The pebbles include andesites, dacites, schists, granites, and quartz sandstones, all thought to be ice-rafted. The sand and gravel contain both planktonic and benthic foraminifers, and subarctic Pleistocene nannofossils. The hole was terminated when the bottom sub of the lower bumper sub failed, dropping the bit and the core barrel. Hole 431A was offset 152 meters $130^{\circ}$ from Hole 431, and penetrated 17.0 meters. Recovery was limited to 4.35 meters of soft sand and fine gravel. The upper 7.5 meters of this section consists of 80 per cent fine iron-manganese oxide fragments and 20 per cent authigenic silicates and phosphates, ice-rafted pebbles and calcareous sand of Quaternary date. The lower 9.5 meters consists of 50 per cent authigenic silicates, 20 per cent iron-manganese oxide fragments, 20 per cent altered basalt, and 10 per cent calcareous sand. The Eocene/Quaternary hiatus is represented in this lower core. The iron-manganese crust and clays are predominantly authigenic and presumably formed by the alteration of volcanic material. Individual fragments contain 24 to 27 weight per cent manganese oxide. The hole was terminated because of shear failure of the bottom sub of the lower bumper sub, again resulting in dropping of the bit and inner core barrel.

\section{Site 432: Nintoku Seamount}

Two holes were drilled at this site, in what appeared from seismic data to be perched lagoonal deposits. At Hole 432, the interval from 0 to 5.5 meters was cored, and 3.0 meters of light green unconsolidated pelagic sediments, consisting principally of Quaternary planktonic foraminifers, was recovered. The lower bottom sub again sheared off at a sub-bottom depth of 17.5 meters. Hole 432A was washed down as far as possible to avoid a repetition of the bottom sub failures. Hard material was first encountered at a sub-bottom depth of 39 meters, and 3.52 meters of well-consolidated sandstone and conglomerate, underlain by a thin red clay above basalt, was recovered. Below the lowest sediments, at a sub-bottom depth of 42.1 meters, three flow units of basalt were recovered, along with a number of basalt pebbles from an overlying conglomerate. The sandstone contains larger foraminifers, planktonic foraminifers, and calcareous benthic foraminifers of Paleocene date. These sediments were deposited in a shallow, warm-water, high-energy environment, and indicate the presence of a nearby organic reef or bank complex. The Eocene/Quaternary hiatus, which is widespread in materials cored from the Emperor Seamount chain to the 
south, is also represented in the Site 432 cores. The history of Nintoku Seamount is apparently similar to that of Ōjin Seamount (Site 430), Yōmei Seamount (Site 431), and Kōkō Seamount (Site 308), where an Eocene/Quaternary hiatus also exists. The three basalt flows are all similar to basalts of the Hawaiian alkalic suite, and probably formed during the post-caldera stage of Nintoku Volcano. The upper two flows are feldspar phyric alkalic basalts, and the lower flow is transitional between alkalic basalt and hawaiite. A red clay soil $10 \mathrm{~cm}$ thick occurs above the lower flow unit (Flow Unit 3). The vesicular tops and bottoms of the flows and the red soil zone show that the flows were erupted subaerially. Nintoku Seamount, like Ōjin Seamount (Site 430), once stood above the sea as a volcanic island.

\section{Site 433: Suiko Seamount}

Four holes, including a multiple re-entry hole, were drilled at this site. Hole 433 was drilled as a wash-down test for the multiple re-entry hole. A 5.0-meter core of foraminiferal nannofossil and diatom-nannofossil ooze was taken to establish mudline. The ooze is upper Pliocene to Pleistocene. The bit was washed to a depth of 45.0 meters before resistance was felt at what later proved to be a chalk bed overlying an ash bed. Hole 433A was continuously cored at the same location as a pilot hole for multiple re-entry. The hole penetrated 163.5 meters of sedimentary rocks and 7.5 meters of basalt. The sedimentary section consists of five lithologic units: (1) Pleistocene foraminiferal nannofossil ooze from 0 to 5.0 meters depth; (2) upper Pliocene through upper Miocene diatom-nannofossil ooze to marly siliceous nannofossil ooze from 5.0 to 43.0 meters; (3) upper Miocene calcareous ooze to calcareous chalk from 43.0 to 52.0 meters; (4) lower Miocene tuffaceous sandy mud, from $\mathbf{5 2 . 0}$ to $\mathbf{5 2 . 5}$ meters, that probably represents an altered volcanic ash layer; and (5) Paleocene shallowwater reef or bank assemblage of carbonate sand and sandy mud with algal nodules, from 52.5 to 163.5 meters. Basalt directly underlies the shallow-water limestone. Hole 433A was abandoned because a wad of fishing net and line fouled the stern thrusters. Hole 433B was spudded in to complete the pilot hole. This hole was washed to a depth of 128.5 meters sub-bottom, recored in the lower 34.5 meters of sedimentary rocks, and finally penetrated 23.5 meters of basalt. The sedimentary section consists of reef or bank carbonate, poorly to moderately well sorted sand, and calcarenites of Paleocene date. The sediment in depositional contact with basalt consists of a well-rounded, well-sorted, and indurated organic carbonate sand. Hole $433 \mathrm{C}$ was spudded in as a multiple re-entry hole. The hole was washed to a depth of 163.0 meters and continuously cored, with three re-entries, to a total penetration depth of 550.5 meters; the lower 387.5 meters were entirely in basalt. More than 100 basalt flow units or flow lobes were identified on board. The upper three flow units are alkalic and underlain entirely by tholeiitic basalts. More than 300 onboard paleomagnetic measurements gave a mean inclination for the Suiko basalts of $40^{\circ} \pm 4^{\circ}(95 \%$ con- fidence level), which corresponds to a latitude of formation of $25^{\circ}$.

\section{PRINCIPAL RESULTS FROM LEG 55}

\section{Introduction}

In terms of fulfilling the objectives laid out before the cruise, Leg 55 was highly successful, despite the operational problems that caused premature termination of the three single-bit holes. Drilling was attempted at four sites on four separate volcanic edifices in the Emperor Seamounts. Basalt was recovered at three of the sites, and the re-entry drilling at Suiko penetrated 550 meters into the seamount, including 387 meters into basalt. Suitable samples for radiometric age measurement, basalt chemistry and lithostratigraphy, and paleomagnetic analysis were recovered from Ōjin, Nintoku, and Suiko seamounts. Shallow-water carbonate sediments relevant to paleolatitude, seamount age, and post-volcanic subsidence history were recovered at all four sites. The biostratigraphic and paleoceanographic objectives were much less successful than those directly related to the hot-spot hypothesis and to the post-volcanic history, primarily because of the paucity of pelagic sediments atop the Emperor Seamounts, the widespread Eocene through Pliocene hiatus found at most of the sites, and the relatively poor sediment recovery.

The principal results of the Leg 55 drilling relating to the tests of the hot-spot hypothesis and to the postvolcanic subsidence history of the seamounts are briefly summarized below. The biostratigraphy is more completely summarized in the paper by Koizumi, Butt, Ling, and Takayama (this volume).

\section{The Hot-Spot Hypothesis}

\section{Ages of Volcanoes and Progression of Volcanism}

Reliable $\mathrm{K}-\mathrm{Ar}$ ages have now been determined for Ōjin, Nintoku, and Suiko, the three seamounts at which volcanic basement was reached by Leg 55 drilling (Dalrymple, Lanphere, and Clague, this volume). In addition, Jingu Seamount, which abuts Ōjin on the north (Figure 1), has been dated using dredged samples recovered by the Hawaii Institute of Geophysics (Dalrymple and Garcia, this volume). Even though the samples from these four seamounts are all altered to some degree, the least altered proved amenable to ${ }^{40} \mathrm{Ar} /{ }^{39} \mathrm{Ar}$ incremental heating techniques, and yielded concordant plateau and isochron ages with isochron ${ }^{40} \mathrm{Ar} /{ }^{36} \mathrm{Ar}$ intercepts indistinguishable from the atmospheric value.

The results from the four newly dated seamounts are summarized in Table 2. The best ages in the last column are the weighted means of the isochron ages, but use of the plateau ages does not substantially change the results. The age data suggest a small age difference between the alkalic and tholeiitic flows from both Ōjin and Suiko, but Dalrymple, Lanphere, and Clague (this volume) point out that the apparent age difference is not statistically significant in view of the analytical uncertainties.

As predicted by the hot-spot hypothesis, the new data show that these four volcanoes are all older than the 

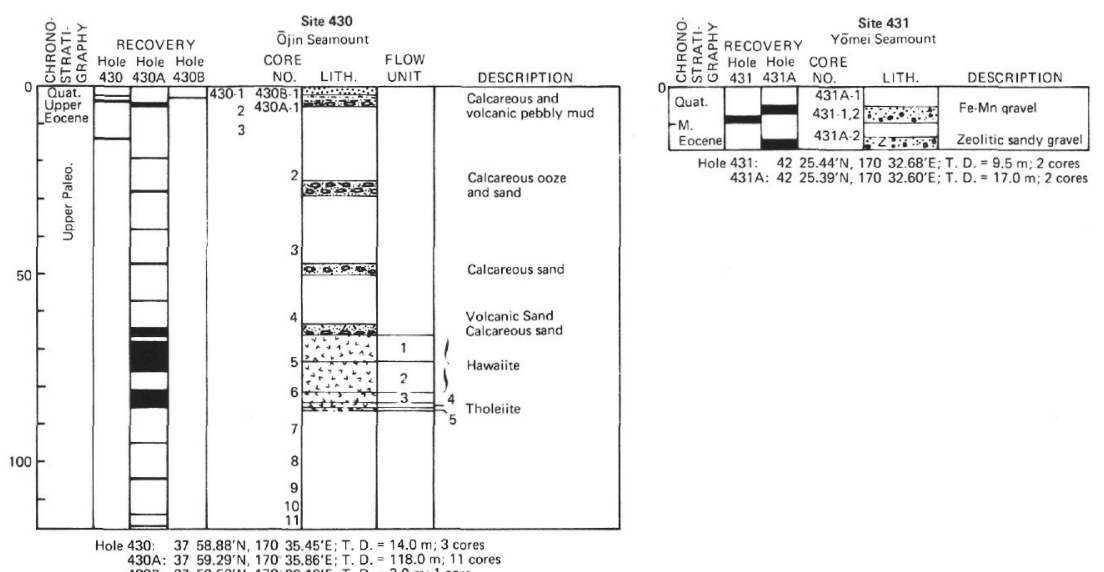

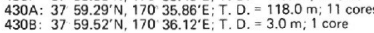

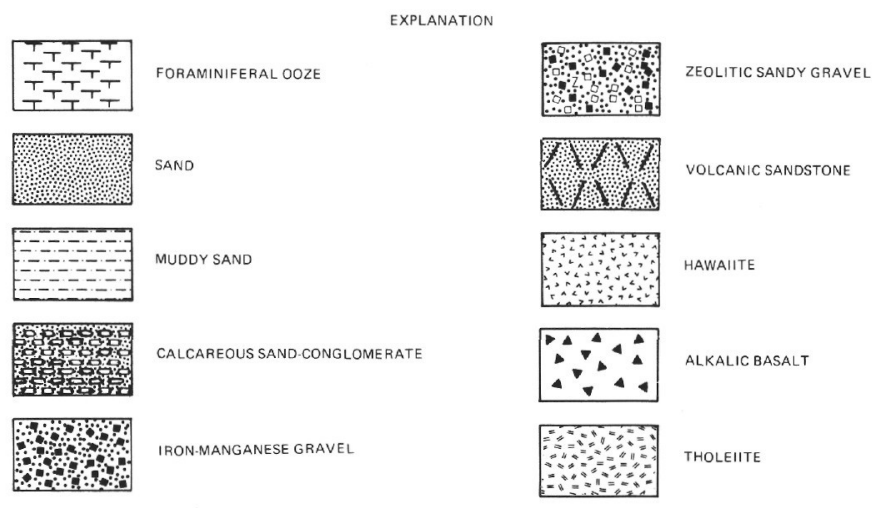

Figure 3. Stratigraphic columns for Sites 430 through 433, Leg 55. 


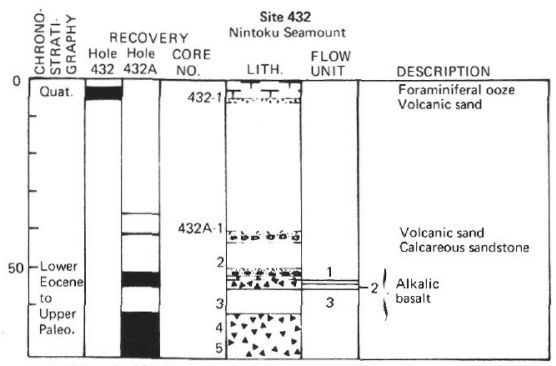

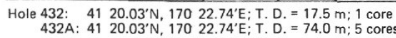

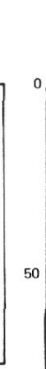



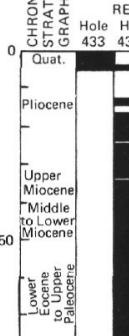

${ }_{100}$
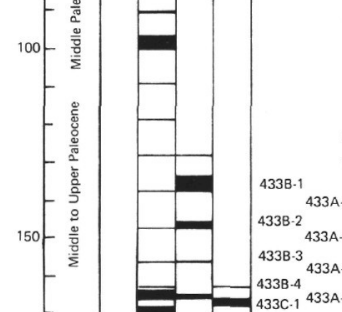

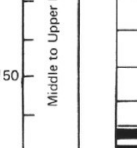

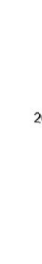


TABLE 2

Summary of Reliable K-Ar Ages from $40_{\mathrm{Ar}} /{ }^{39} \mathrm{Ar}$ Incremental Heating Experiments for Ojin, Jingū, Nintoku, and Suiko Seamounts, Emperor Seamount Chain a

\begin{tabular}{lclcc}
\hline Seamount & $\begin{array}{c}\text { Flow Unit } \\
\text { (or Sample No.) }\end{array}$ & Rock Type & $\begin{array}{c}\text { Isochron Age } \\
\left(10^{6} \text { years }\right)\end{array}$ & $\begin{array}{c}\text { "Best Age" } \\
\text { for volcano } \\
(106 \text { years) }\end{array}$ \\
\hline$\overline{\text { Ojjin }}$ & 1 & Hawaiite & $54.7 \pm 0.5$ & \\
& 3 & Hawaite & $55.6 \pm 0.5$ & $55.2 \pm 0.7$ \\
Jingu & 5 & Tholeiite & $57.0 \pm 2.0$ & \\
& $(24-10 \mathrm{~B})$ & Mugearite & $54.7 \pm 0.8$ & \\
Nintoku & $(24-10 \mathrm{C})$ & Mugearite & $55.4 \pm 0.9$ & $55.4 \pm 0.9$ \\
Suiko & 3 & Alkalic Basalt & $56.2 \pm 0.2$ & $56.2 \pm 0.6$ \\
& 1 & Alkalic Basalt & $63.0 \pm 1.5$ & \\
\hline
\end{tabular}

aData from Dalrymple, Lanphere, and Clague (this volume) and Dalrymple and Garcia (this volume).

Hawaiian-Emperor bend (43 m.y.) and Kōkō Seamount (48 m.y.) (Dalrymple and Clague, 1976), both to the south. The age determined for Suiko Seamount (Table 2 ) is somewhat greater than the $59.6 \mathrm{~m}$.y. reported for a dredged sample of mugearite by Saito and Ozima (1975, 1977). In addition to the obvious problem of identifying an indigenous sample among the ice-rafted material recovered in the Suiko dredge hauls, Dalrymple, Lanphere, and Clague (this volume) have expressed reservations about the reliability of the age data obtained by Saito and Ozima. They also point out, however, that the Suiko dredge haul is probably from a different volcanic center than the Leg 55 cores, and that the differing results for Suiko are not necessarily inconsistent with the Leg 55 results.

The ages of the oldest sediments above basalt at Ōjin, Nintoku, and Suiko seamounts are consistent with the $\mathrm{K}$-Ar ages. The oldest sediments at Ōjin were recovered from Hole 430A, where 47.5 meters of calcareous ooze and sand interbedded near the base with 11.8 meters of volcaniclastic sand directly overlies basalt. Sediment recovery was very poor at this site, but Cores 1 through 3 contain a mixed assemblage of poorly preserved calcareous nannofossils ranging from Paleocene to Pleistocene (Takayama, this volume). The presence of Discoaster multiradiatus throughout the section, however, indicates that these sediments are probably upper Paleocene (NP 9, approximately 55 to 57 m.y.), and that the younger specimens are up-hole contamination. Rare pelagic foraminifers in Cores 1 through 3 (Hagn et al., this volume; Butt, this volume) also indicate the upper Paleocene, specifically the Globorotalia pseudomenardii Subzone (approximately 57 to 59 m.y.).

At Nintoku Seamount, the oldest sediments recovered consist of fossiliferous volcanic sandstone that contains upper Paleocene planktonic foraminifers and lower Eocene (?) benthic foraminifers (Butt, this volume). Calcareous nannofossils are absent in these sediments.

The sediments immediately above basalt at Site 433 on Suiko Seamount consist of biogenic carbonate sand and calcarenite. These sediments contain calcareous nannofossils indicative of middle Paleocene, either NP 5 or NP 6 (approximately 59 to 61 m.y.) (Takayama, this volume). Planktonic foraminifers are rare in these sands, but the limited assemblage suggests a date of late to middle Paleocene, in agreement with the calcareous nannofossils (Butt, this volume; Hagn et al., this volume). It is interesting that one sample from Hole 433A (Core 7, Section 1) contains two reworked and doubtful specimens of Maestrichtian Globotruncana, suggesting that parts of Suiko nearby may be overlain by sediments older than those at Site 433 . The mixed volcanic-carbonate sand recovered between basalt Flow Units 1 and 2 , contains calcareous nannofossils suggestive of zones NP 7 to NP 10, and may thus be younger contaminating material originally from above Flow Unit 1 .

The new K-Ar age data for Ōjin, Jingū, Nintoku, and Suiko seamounts bring to 27 the number of volcanic centers in the Hawaiian-Emperor chain for which radiometric ages have been determined. Data are now available from along the length of the Hawaiian segment of the chain, around the bend, and more than halfway up the Emperor Seamounts, providing an adequate data base for a reasonable test of the age-progression corollary of the hot-spot hypothesis. These data are plotted in Figure 4 and tabulated by Dalrymple, Lanphere, and Clague (this volume). The age progression for the Emperor chain, based on foraminiferal data, is shown in Fig. 14 of Butt (this volume), and is consistent with the K-Ar data.

The northernmost dated volcano is Suiko (Site 433). An attempt to date the basalts recovered from Meiji Seamount by Leg 19 drilling yielded only a minimum $\mathrm{K}-\mathrm{Ar}$ age of $62 \pm 5 \mathrm{~m}$.y. (Dalrymple, Lanphere, and Natland, this volume), and thus did not improve on the minimum age provided by the lower Maestrichtian (70 to $73 \mathrm{~m} . \mathrm{y}$.) nannofossils from the overlying sediments (Worsley, 1973).

The K-Ar data clearly prove the general prediction that the volcanoes increase in age with distance from Kilauea, and demonstrate that the Emperor Seamounts are a continuation of the Hawaiian volcanic chain. A

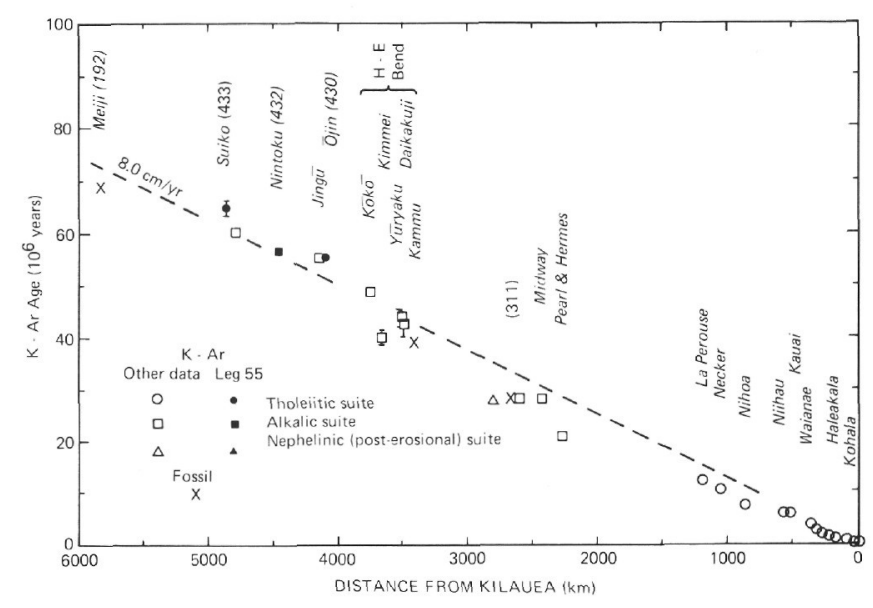

Figure 4. Radiometric ages of volcanoes in the Hawaiian-Emperor chain as a function of distance from Kilauea Volcano. Fossil minimum ages are shown only where radiometric data are unavailable. From Dalrymple, Lanphere, and Clague (this volume). 
least-squares fit to all the data and forced through Kilauea yields a volcanic propagation rate of $8.2 \mathrm{~cm} /$ year. The data do not indicate any change in volcanic propagation rate at the bend, although a change at about Midway time is permissible. A least-squares fit to the data from Kilauea to Midway forced through Kilauea gives a volcanic propagation rate of $9.9 \mathrm{~cm} /$ year. A fit to the data from Midway to Suiko gives a rate of $6.3 \mathrm{~cm} /$ year.

Although a change in volcanic propagation rate about Midway time is permissible, it is not necessarily required. Jackson (1976) has pointed out that there are several reasons why the apparent volcanic propagation rate may not be exactly linear. These include incorrect age data and dates on samples from different stages of volcanism; the latter would represent different times in the history of the volcanoes. It is also possible that the data in Figure 4 reflect, in part, real changes in the volcanic propagation rate. Jackson et al., (1972) first proposed that volcanism along the chain proceeded episodically along curved, en-echelon loci, and that volcanoes lying along parallel segments of these loci might be coeval. On the basis of these ideas, Jackson and Shaw (1975) hypothesized that these loci were related to the stress fields in the Pacific plate. Jackson et al. (1975) and Shaw et al. (in press) have also pointed out that simple linear treatment of the volcanic propagation rate may not reflect the motion of the Pacific plate relative to the hot spot. They have treated the Hawaiian-Emperor age data as a function of fictive "collapsed" distances and calculated a "real" propagation rate for plate motion relative to the hot spot of $5.9 \mathrm{~cm} /$ year for the interval from 74 to 1.4 m.y.B.P.

In view of the various uncertainties in the age data along the chain, we are not certain that anything more than a simple linear treatment is justified at this time. The non-linear propagation hypothesis of Jackson et al. (1972), Jackson et al. (1975), and Shaw et al. (in press), however, deserves serious consideration as an alternative hypothesis.

\section{Hawaiian Hot-Spot Fixity}

One of the most important questions addressed by the Leg 55 experiment was that of hot-spot fixity. The primary purpose of the re-entry hole at Suiko was to obtain a number of samples for paleomagnetic study sufficient that a reliable paleolatitude of formation could be determined for a volcano in the central Emperor Seamounts. It was also hoped that data from temperaturedependent fossils in the sediments above basalt would provide additional if semiquantitative information about the latitude of formation and subsidence of the seamount. Both of these objectives were fulfilled.

More than 450 paleomagnetic samples for paleolatitude determination were collected from 5 flow units on Ōjin (Site 430), 3 flow units on Nintoku (Site 432), and 65 flow units on Suiko (Site 433) seamounts (Kono, this volume). All the samples from these three seamounts have reversed polarity and magnetic inclinations indicating paleolatitudes far south of their present positions. Only the data from Suiko, however, are sufficient in number to yield an independent and reliable paleolatitude.

A variety of tests indicate that the lavas from the three seamounts are magnetically stable and that the NRMs are essentially the magnetization acquired when the rocks originally cooled (Kono, Chapters 34 and 35, this volume; Kono, Clague, and Larson, this volume): (1) eighty per cent of the samples have Curie temperatures above $500^{\circ} \mathrm{C}$; (2) the mean demagnetizing field (MDF) for most of the flow units is above 150 oersteds (Oe) and most have MDFs of 300 Oe or higher; (3) the dominant magnetic mineral in the flows is titanomagnetite that has undergone high-temperature oxidation; and (4) most of the magnetic grains are in the single domain or pseudo-single domain range with small initial susceptibility, large Königsberger ratio, and a high ratio of saturation remanent magnetization to saturation magnetization.

In addition to the stability of the remanent magnetization, a key question in paleomagnetic studies of paleolatitude is whether sampling is sufficient to average out paleosecular variation (PSV) so that the measured paleomagnetic inclination represents the paleoinclination of the main dipole field at the site. The numbers of flows from Ōjin and Nintoku are clearly too small to adequately sample the PSV, but the sampling of Suiko (Site 433) is sufficient so that PSV has probably been averaged out. Even when certain flows thought to represent a very short time are grouped, there is still a minimum of 40 independent data. A significant feature of these data is that such grouping does not significantly change either the mean inclination or the associated statistical parameters. There are also 12 places in the core where the inclination changes by more than $15^{\circ}$ (Figure 5), which indicates that at least 13 PSV "cycles" have been sampled.

From the change in inclination with depth and the observation that all of the flows have reversed polarity, Kono (this volume) estimates that the time represented in the Suiko basalt core is at least $10^{4}$ but less than $1.5 \times$ $10^{6}$ years. This interval is long enough so that the PSV is averaged out, but short enough so that the effects of plate motions, polar wandering, polarity reversals, and field excursions may be ignored.

The mean inclination for the Suiko lava flows is $45.7^{\circ} \pm 4.8^{\circ}$, which corresponds to a paleolatitude of $26.9^{\circ} \pm 3.5^{\circ}$ at the 95 per cent confidence level. This is significantly different from the present latitudes of both Site $433\left(44.8^{\circ} \mathrm{N}\right)$ and Kilauea $\left(19.5^{\circ} \mathrm{N}\right)$.

The paleolatitudes from several sites along the Hawaiian-Emperor chain are plotted in Figure 6 as a function of age. The data from Meiji, Nintoku, Ōjin, and Midway are ali based on a small number of flows, and it is doubtful that PSV is adequately averaged out. In addition, the dispersions of the virtual geomagnetic poles for the Midway and Meiji data are unusually small, which also suggests that there is insufficient sampling of the PSV.

The paleolatitude of $17.5^{\circ} \pm 5^{\circ}$, determined for Suiko by Kodama et al. (1978) from magnetic survey data, is inconsistent with the paleomagnetic results from the Leg 


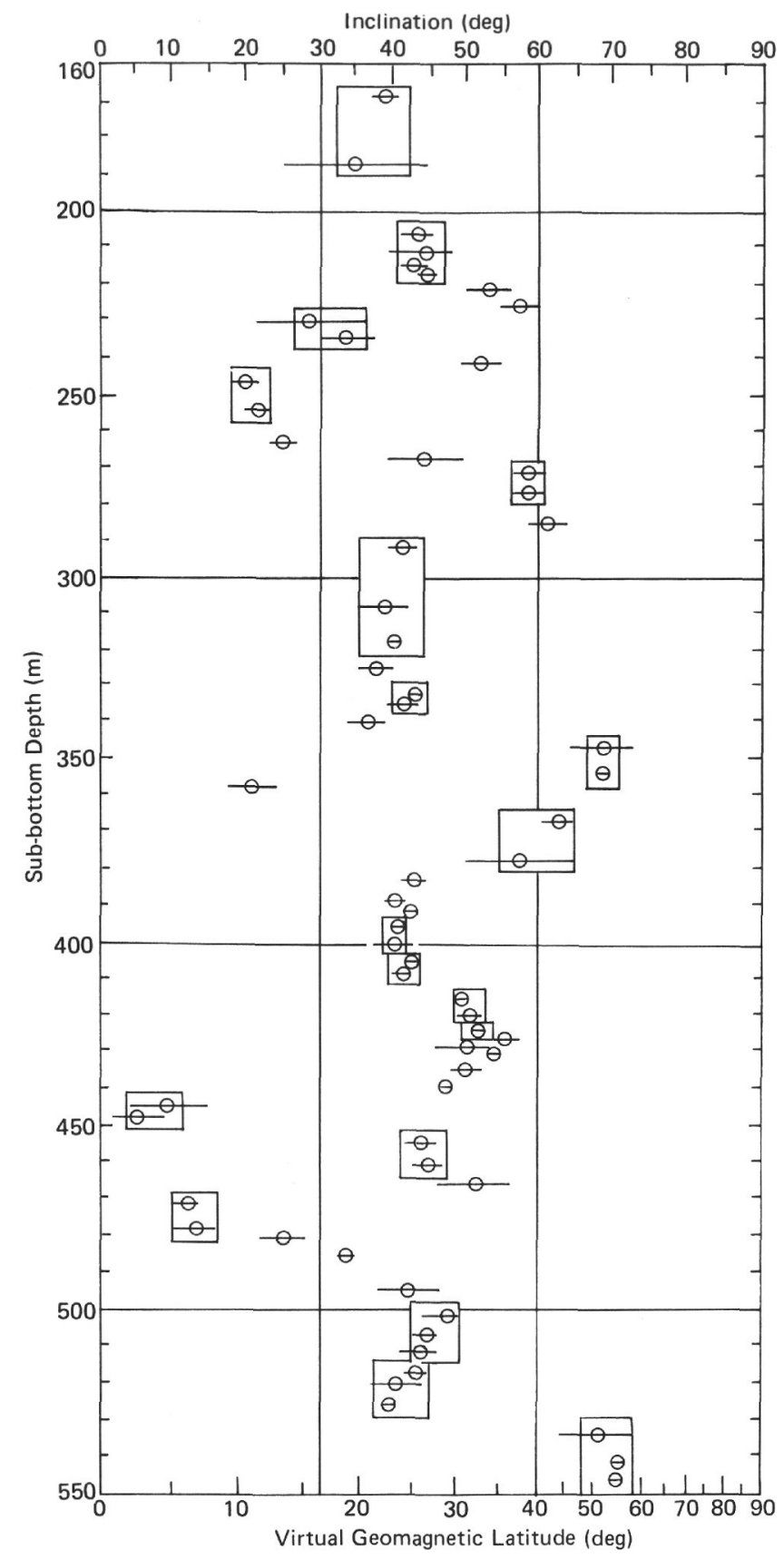

Figure 5. Flow mean inclination versus depth at Site 433 (Suiko Seamount). Error bars are $\alpha_{95}$; boxes indicate flow units combined to form groups thought to represent single points in time. After Kono (this volume).

55 samples (Figure 6). There are several reasons, however, to suspect the accuracy of this result. First, the test-of-fit statistic $(R=1.1)$ is low. Second, Suiko is probably constructed from several coalesced volcanoes (Bargar and Jackson, 1974), possibly of different ages (Dalrymple, Lanphere, and Clague, this volume), and the assumption of uniform magnetization may be invalid. A recent and similar study of Mt. Shasta, a Quater-

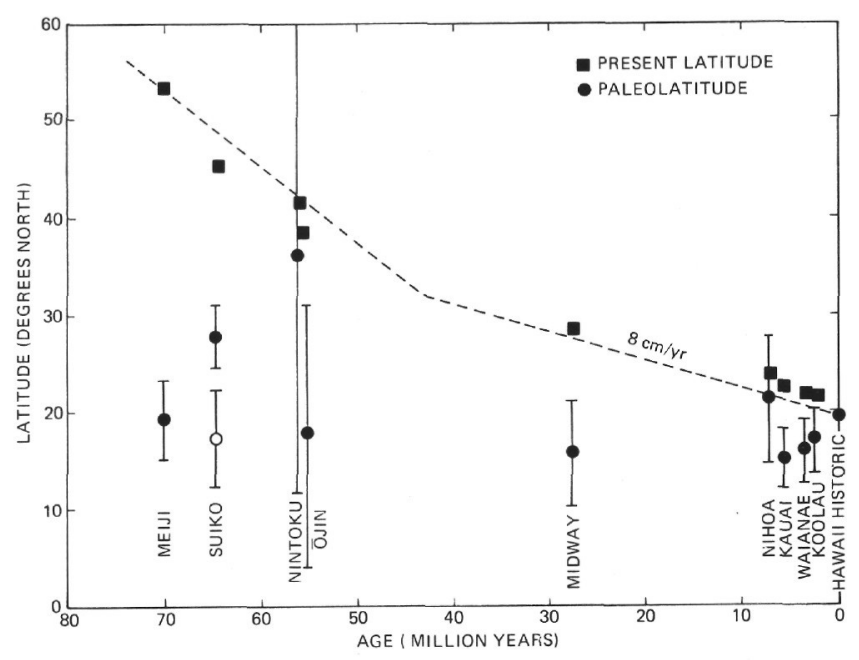

Figure 6. Paleolatitude versus age for volcanoes along the Hawaiian-Emperor chain. Squares indicate present latitudes, filled circles indicate paleolatitudes determined from paleomagnetic data. Open circle indicates paleolatitude for Suiko, determined from shipboard magnetic survey. Error bars are $\alpha_{95}$. Dashed line represents the backtracked position of the hot spot relative to the Pacific plate, assuming a constant velocity of $8 \mathrm{~cm} /$ year along the Hawaiian-Emperor chain. Paleomagnetic data from summary of Kono (this volume), age data from summary of Dalrymple, Lanphere, and Clague (this volume), magnetic survey point for Suiko from Kodama et al. (1978).

nary volcano in California, resulted in a calculated inclination corresponding to a latitude $15^{\circ}$ south of its present position, even though the test-of-fit parameters suggest a reliable result (Blakely and Christiansen, 1978).

Even though there is some doubt about the reliability of many of the individual paleolatitudes, the data taken as a whole (Figure 6) are consistent with the hypothesis that the Hawaiian hot spot has been at relatively low latitudes for the last $70 \mathrm{~m} . \mathrm{y}$. and that the volcanoes are at their present positions largely because of plate motion relative to the earth's spin axis. The Leg 55 data for Suiko, however, indicate that the hot spot has not been exactly fixed, but may have moved southward $7^{\circ}$ or so since Suiko was formed 65 m.y. ago.

The biofacies represented by the Paleogene shallowwater carbonate sediments above the basalt provides semiquantitative substantiation of the Suiko paleolatitude. The bioclastic sediments on Suiko, Nintoku, and Ōjin seamounts consist primarily of corralline algae and bryozoa with ostracodes, foraminifers, and assorted shell fragments typical of a shallow-water, high-energy environment (Butt, this volume; McKenzie et al., this volume). Only a single coral was found in the Suiko material (Hagn et al., this volume), and none was recovered from either Nintoku or Ōjin. This may be a result, in part, of the drill site locations, which were chosen largely for the presence of a reasonable thickness of 
soft overlying sediments required for spudding in the drill string, and are in lagoonal deposits. What appear to be reefs, acoustically opaque units often underlain by bedded reflectors, are clearly visible on the seismic records for these seamounts (Greene et al., 1978; Greene et al., this volume; Dalrymple, Greene, Ruppel, Bear, and Clague, this volume) but apparently the reefs are discontinuous and corals were not significant contributors to the carbonate buildups.

Schlanger and Konishi (1975) have pointed out that carbonate buildups in the Pacific can be divided into the Bryozoan-Algal and the Coral-Algal facies, the distribution of which depends largely on water temperature and solar insulation, and thus is also a function of latitude, although there are local factors as well. They observed that in the modern Pacific, the Coral-Algal facies dominates at latitudes below about $20^{\circ}$, whereas the Bryozoan-Algal facies is predominant above about $30^{\circ}$ latitude. They locate the boundary between these facies at about $25^{\circ}$ latitude, but emphasize that the transition is gradual. In the central Pacific, the annual surface water temperature at $25^{\circ}$ latitude is about $22^{\circ} \mathrm{C}$ (Muromtsev, 1958), which is often taken as the minimum for active coral-algal reef growth (Vaughan and Wells, 1943; Heckel, 1974). The optimum temperature for vigorous reef growth is $25^{\circ} \mathrm{C}$ to $29^{\circ} \mathrm{C}$.

The existence of carbonate sediments of the Bryozoan-Algal facies atop the central Emperor Seamounts drilled on Leg 55 suggests that these volcanoes formed in waters somewhat cooler than those presently at the latitude of Hawaii (McKenzie et al., this volume), i.e., less than $25^{\circ} \mathrm{C}$. From the biofacies model of Schlanger and Konishi (1975), the water temperature would be less than about $22^{\circ} \mathrm{C}$. Using the oxygen isotope temperature data of Savin et al. (1975) for the North Pacific, Greene et al. (1978) reconstructed the approximate latitude variation through time for the $20^{\circ} \mathrm{C}$ and $22^{\circ} \mathrm{C}$ isotherms (Figure 7). They showed that if the Hawaiian hot spot were fixed, then Suiko Seamount would have formed in water warm enough to have developed active coral-algal reefs. Following the analysis of Greene et al. (1978), if Suiko is plotted at the latitude determined by the paleomagnetic data of Kono (this volume), then the temperature would be cooler than $22^{\circ} \mathrm{C}$ and appropriate for the Bryozoan-Algal facies.

The paucity of coral material on seamounts in the central Emperor chain is in contrast to Kōkō and the seamounts on the bend, where corals are more common but still less abundant than in a region of vigorous coral reef growth (Davies et al., 1971, 1972; Matter and Gardner, 1975; McKenzie et al., this volume). If the hot spot was at $27^{\circ} \mathrm{N}$ latitude when Suiko formed and moved progressively to its present position between Suiko time and bend time, then the volcanoes in the central and southern Emperor Seamounts would have formed in progressively warmer waters (Figure 7). This would also be true if the hot spot motion was continuous between Suiko time and the present, but the temperature increase from Suiko time to bend time would have been less.

McKenzie et al. (this volume) have measured the oxygen isotope temperatures of carbonate diagenesis for

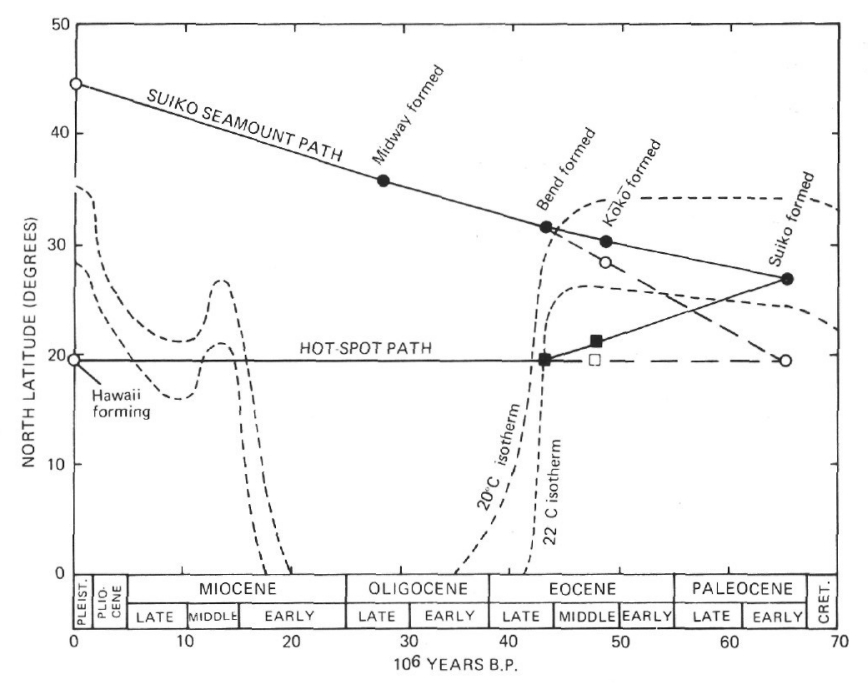

Figure 7. Approximate positions of the $20^{\circ} \mathrm{C}$ and $22^{\circ} \mathrm{C}$ surface water isotherms in the north-central Pacific during the Cenozoic, after Greene et al. (1978), based on the data of Savin et al. (1975). Filled circles are the paleolatitudes of Suiko assuming that Suiko formed at $26^{\circ} \mathrm{N}$, and that the hot spot has been fixed since bend time. Open circles presume a fixed hot spot. Squares show the positions of formation of Kōko and the bend under the same assumptions. Backtracking was about an Emperor pole at $17^{\circ} \mathrm{N}, 107^{\circ} \mathrm{W}$ and a Hawaiian pole at $69^{\circ} \mathrm{N}, 68^{\circ} \mathrm{W}$ (Clague and Jarrard, 1973). The $22^{\circ} \mathrm{C}$ isotherm is the approximate boundary between the Coral-Algal (warmer) and the Bryozoan-Algal (colder) facies of Schlanger and Konishi (1975). Time scale from this volume.

Suiko, Nintoku, Ōjin, Kōkō, and Kammu seamounts (Figure 8), and report a warming from Suiko to Kōkō that they attribute to the overall rise in the temperature of intermediate waters during the earliest Neogene (Savin, 1977). The change in diagenetic temperature appears, however, to be greater than can be accounted for by the rise in bottom water temperature measured by Savin (1977), and it is likely that southward migration of the hot spot also played a role. The diagenetic temperature is also greatly affected by water depth, and since the depth of diagenesis is not known, this effect can not be quantitatively evaluated. It seems unlikely, however, that the temperature increase measured by McKenzie et al. (this volume) is due entirely to depth, especially since the low diagenetic temperature measured for Kammu Seamount corresponds nicely to the rapid drop in ocean temperature during the late Eocene and early Oligocene (Figure 8).

Although the paleomagnetic and biofacies data collected on Leg 55 strongly suggest that the Hawaiian hot spot was at a latitude of $27^{\circ} \mathrm{N} 65 \mathrm{~m}$.y. ago, this does not necessarily mean that the Hawaiian hot spot has moved relative to the worldwide hot-spot frame. Morgan (personal communication, 1977) has proposed the alternative hypothesis that the Suiko result is due to a shift of the entire hot-spot frame, the deep mantle, and the crust 


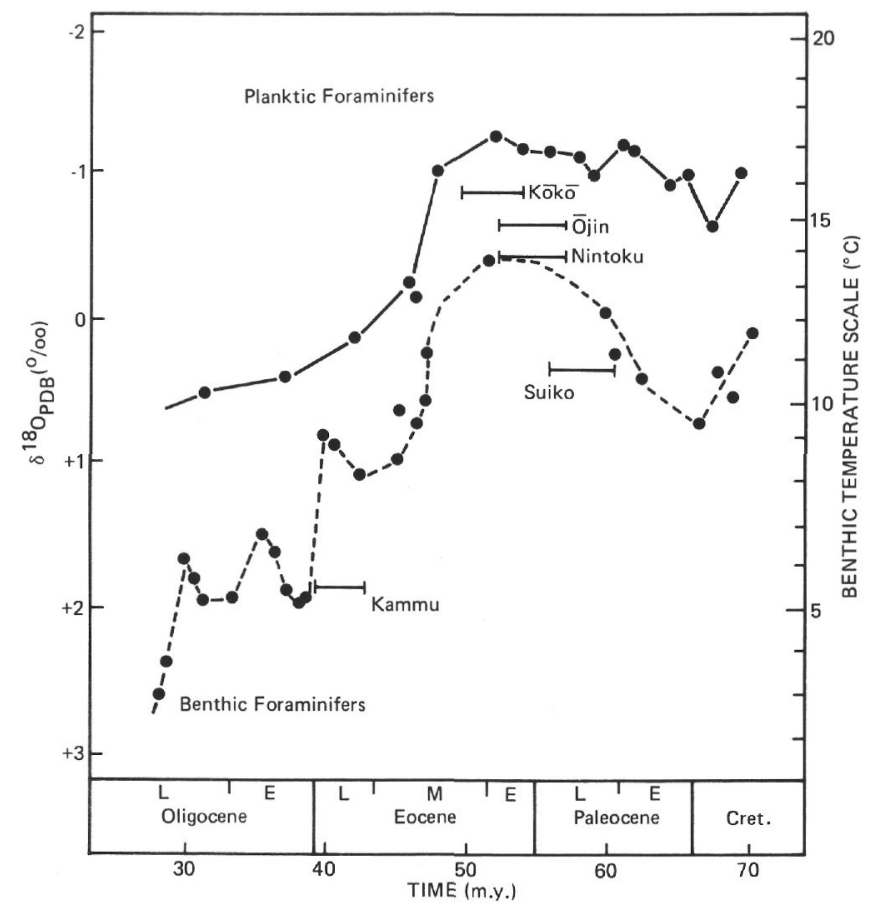

Figure 8. Isotopic paleotemperatures of carbonate diagenesis for Emperor and bend seamounts (McKenzie et al., this volume) compared with bottom water (benthic) temperatures and equatorial surface water (planktic) temperatures of the North Pacific (Savin, 1977). For planktic temperatures, add approximately $2.5^{\circ} \mathrm{C}$ to the benthic temperature scale.

relative to the spin axis: i.e., true polar wander. Paleomagnetic data and the observed change in the latitude of worldwide International Latitude Service observatories since 1900 suggests that polar wander relative to the hotspot frame is not unreasonable. Such a shift might be caused by a change in the distribution of mass of the earth (opening of a new trench, etc.), which would result in a change in the moment of inertia, and could occur quite rapidly. This is an appealing possibility because it permits the Hawaiian hot spot to be fixed in the mantle but at the same time allows Suiko to be formed at the paleomagnetically determined latitude. Although Jurdy and Van der Voo (1975) concluded that true polar wander since the Cretaceous was small or nonexistent, the shift required to reconcile the Suiko paleolatitude with the hypothesis of a fixed Hawaiian hot spot is within the uncertainties of their analysis.

Several models involving more prolonged hot-spot motion are also possible. Continuous southward migration of the hot spot from $65 \mathrm{~m} . \mathrm{y}$. ago to the present is obviously possible if the motion of the Pacific plate relative to the spin axis is adjusted to follow the geometry of the Hawaiian-Emperor chain. McDougall (1971) proposed that the hot spot and the Pacific plate moved in opposite directions but at equal velocity. Such counter motion, when backtracked along the chain, brings the hot spot and Suiko Seamount into coincidence at a latitude of about $32^{\circ} \mathrm{N}$, which does not agree with the Suiko paleomagnetic result (Figure 9, model 2). Equal but

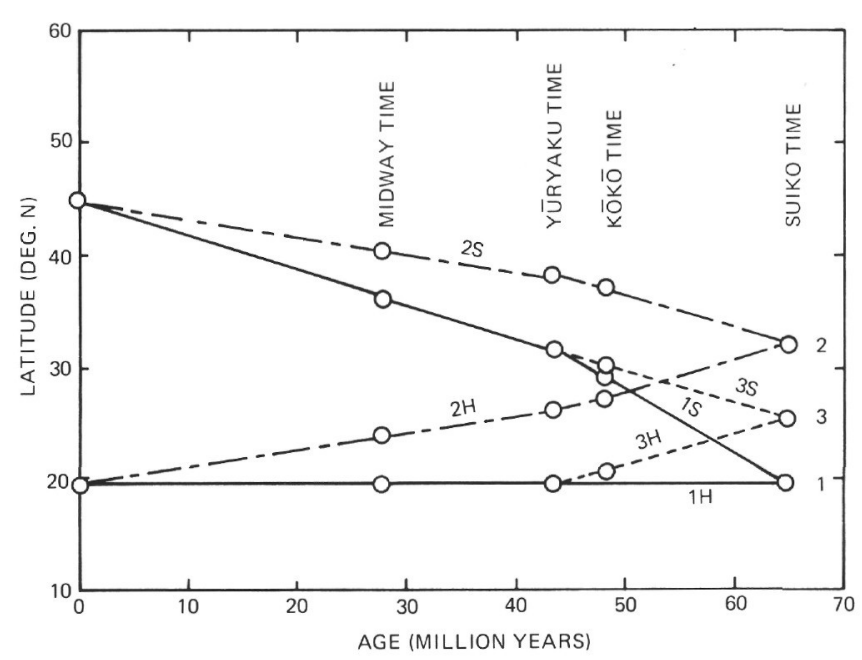

Figure 9. Latitudes of the Hawaiian hot spot $(H)$ and Suiko Seamount (S) as a function of time for three motion models:(1) hot spot fixed; (2) hot spot and Suiko move in opposite directions at equal velocities; (3) hot spot and Suiko move in opposite directions at equal velocities from Suiko time to bend (Yurryaku) time, then hot spot fixed. Poles of rotation are the same as in Figure 7.

opposite motion from Suiko time to bend time, followed by a fixed hot spot from bend time to the present, however, results in a hot-spot latitude of $26^{\circ} \mathrm{N}$ when Suiko formed (Figure 9, model 3) - an interesting coincidence.

Although the Leg 55 results indicate that the Hawaiian hot spot has moved southward a few degrees during the last $65 \mathrm{~m} . \mathrm{y}$., there are other data that suggest otherwise. Hammond et al. (1979) have determined the paleolatitudes for central equatorial sites in the Pacific during the Neogene using sediment cores. They calculate a northward velocity component for the Pacific plate of about $6 \mathrm{~cm} /$ year, which is approximately twice the northward rate determined from the migration of volcanism along the Hawaiian chain, and conclude that the Hawaiian hot spot may have moved northward during that period.

Another problem yet to be resolved is the exact relationship between Pacific sea-floor spreading, worldwide plate motion, and the origin of the Hawaiian-Emperor bend. Reconstruction of the North Pacific based on the magnetic anomaly pattern (Figure 10) indicates that the Kula Ridge became inactive about anomaly 23 time, i.e., 55 to 57 m.y.B.P., or 10 to 15 m.y. before formation of the bend (Scientific Staff, 1978; Byrne, 1979). The demise of the Kula Ridge, however, seemingly had no effect on the geometry of the Hawaiian-Emperor chain, suggesting that the ridge was playing a passive role in the northward component of Pacific plate motion. Likewise, there seems to have been no significant change in either spreading or subduction around the Pacific plate at bend time. If the Hawaiian hot spot has been approximately fixed, then the Hawaiian-Emperor bend represents a drastic change in Pacific plate motion. Since the motions of individual plates are not indepen- 

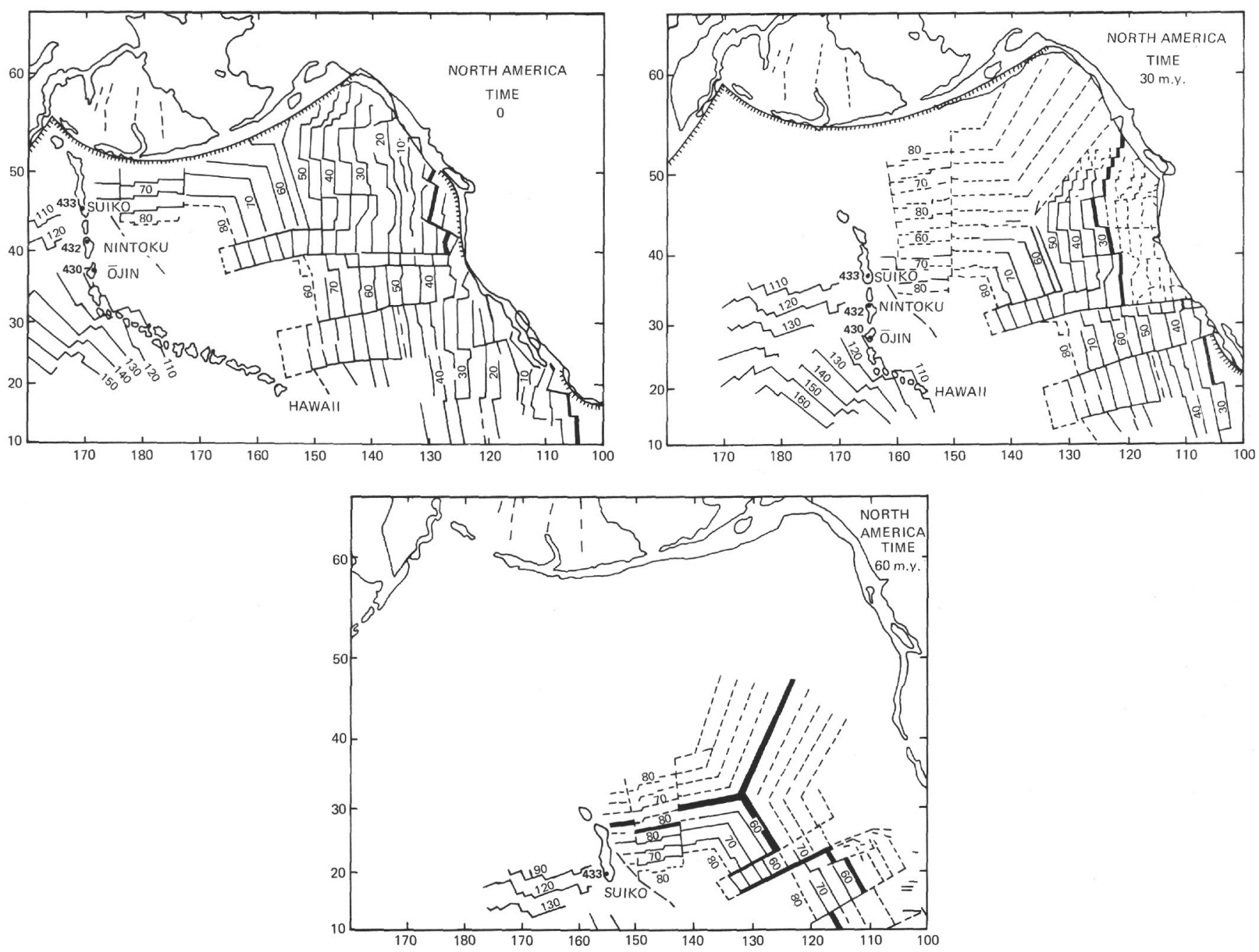

Figure 10. Reconstructions of the Pacific plate in a "fixed hot spot frame". The Pacific plate has been backed up over the Hawaiian-Emperor chain and the Farallon and Kula plates placed in proper relation to the Pacific plate on the basis of magnetic anomalies. North America is farther east in the earlier figures; its motion is determined by hot-spot tracks in the Atlantic Ocean. The Emperor Seamounts initially changed latitude rapidly as the Pacific plate carried them northward toward the Aleutian Trench. Later they moved northward more slowly as Pacific plate motion carried them northwestward. The Kula Ridge appears to have become inactive about 55 m.y.B.P. These reconstructions do not take into account the $27^{\circ} \mathrm{N}$ paleolatitude of Suiko. From Scientific Staff (1978).

dent, we would expect such a significant change to be part of a worldwide reorganization of both absolute and relative plate motions. Several authors have suggested that the Hawaiian-Emperor bend might correlate with circumpacific tectonic events (Jackson et al., 1972; Clague and Jarrard, 1973) or may have been caused by the collision of India and Eurasia (Dalrymple and Clague, 1976). As yet, however, there is still no solid link between the bend and any other major tectonic event, and the cause of the drastic change in the motion of the world's largest plate $43 \mathrm{~m}$.y. ago seems curiously elusive.

Thus, although the Leg 55 paleomagnetic results answered the question the experiment was designed to address, there still remain unresolved problems. The volcanoes of the Hawaiian-Emperor chain contain a unique and permanent record of the history of Hawaiian hot spot and Pacific plate motion for the past 70 to $75 \mathrm{~m}$.y. So far, only a very small portion of this record has been read.

\section{Petrology, Geochemistry, and Lithostratigraphy of the Volcanoes}

As discussed above, the compositions, sequence, and relative volumes of the lava types erupted by Hawaiian volcanoes are unique. Petrologic and geochemical studies on the lavas recovered from Ōjin, Nintoku, and Suiko seamounts on Leg 55 and from Jingū Seamount by the Hawaii Institute of Geophysics confirm the hypothesis that the Emperor volcanoes, at least as far north as Suiko, are very similar to their Hawaiian counterparts. The rock types recovered from these seamounts include 
hawaiite, mugearite, alkalic basalt, and tholeiitic basalt, in the sequence and relative volumes expected for Hawaiian volcanoes. All have a mineralogy and wholerock major- and trace-element chemistry well within the range of rock types found in the Hawaiian Islands and the western Hawaiian Ridge (Kirkpatrick et al.; Bence et al.; Dalrymple and Garcia; Lanphere et al.; Clague et al; Clague and Frey; Avdeiko et al.; Cambon et al.; this volume). Variations in major- and trace-element chemistry along the chain are small and are within the range of variations found within single volcanoes and between adjacent volcanoes. The $\mathrm{Sr}$-isotope ratios provide the only evidence of systematic changes along the chain. Thus, the geochemical data provide strong support for the hypothesis that the volcanoes in the Hawaiian-Emperor chain were generated by a common mechanism operating more or less continuously over at least the last 65 m.y.

Where the stratigraphic relationships can be observed, the sequence of lava types on the seamounts is the same as on the Hawaiian Islands, where lavas of the alkalic suite, primarily hawaiites, mugearites, and alkalic basalts, overlie tholeiitic basalts. At Ōjin, four flows of hawaiite overly a flow of tholeiitic basalt, in which the deepest hole bottomed. Although the extent of the Ojin tholeiites is not known, the stratigraphic relations between the hawaiites and the tholeiitic basalt is that expected for a Hawaiian volcano, and the number of hawaiite flows is typical for the alkalic suite in the Hawaiian Islands. At Suiko, the drilling penetrated at least 114 flows or flow lobes of tholeiitic basalt underlying three flows of alkalic basalt. As at Ōjin, the lithologic sequence and the thickness of the alkalic cap is typical for a Hawaiian volcano. In addition, the extensive section of tholeiitic basalt indicates that the main edifice of Suiko is probably composed of tholeiite, as are the volcanoes in the Hawaiian Islands. Tholeiite was not found on Nintoku Seamount, but the drill penetrated only 32 meters into the edifice and bottomed in alkalic rocks. In addition, numerous small pebbles of hawaiite, mugearite, and alkalic basalt were found in the conglomerate overlying the three Nintoku flows. Only mugearite was found in the dredged material on Jingū (Dalrymple and Garcia, this volume), but shallow dredges from the tops of volcanoes along the western Hawaiian Ridge and on the bend more frequently recover lavas of the alkalic suite than of the tholeiitic suite (Clague, 1974). In the remainder of this section we will summarize the postcruise results for each site and then examine variations in chemistry along the Hawaiian-Emperor chain.

\section{Ōjin Seamount: Site 430}

The major- (Table 3) and trace-element (Table 4) chemistry of the Ōjin flows suggests that the hawaiites formed by differentiation of an alkalic basalt parent, and that the tholeiitic basalt has undergone considerable shallow crystal fractionation. (Kirkpatrick et al., this volume). The mineral composition data (Clague et al., this volume) indicate that the hawaiites are similar to those in the Hawaiian Islands that are erupted during the post-caldera alkalic stage, rather than to those erupted during the post-erosional (nephelinic) stage. The tholeiitic basalt contains plagioclase $\left(\mathrm{An}_{80}\right)$ that is too calcic to be in equilibrium with a magma having the composition of the bulk rock. This suggests that the tholeiite lava formed by a complex sequence of processes, including fractionation and magma mixing, similar to that proposed for Kilauean lavas (Wright and Fiske, 1971).

The rare earth element (REE) patterns for both the hawaiites and the tholeiite from Ōjin (Figure 11) are distinctive in that they have only slightly fractionated light REE but more strongly fractionated mid-to-heavy REE (Bence et al., this volume). The hawaiites show strong enrichment in both the light REE (115-135 $\times$ chondrites) and heavy REE (13-20 × chondrites), indicating extensive shallow crystal fractionation. The tholeiitic flow has much lower REE abundances $(\mathrm{La}=38$ $\times$ chrondrites, $\mathrm{Lu}=9 \times$ chrondrites) than the hawaiites, and it closely resembles Mauna Loa tholeiites. The ${ }^{87} \mathrm{Sr} /{ }^{86} \mathrm{Sr}$ ratios of the hawaiites (average $=0.7035$ ) and the tholeiite (average $=0.7033$ ) are generally lower than the ratios in tholeiitic flows from the Hawaiian Islands (Lanphere et al., this volume). In addition, the Ōjin hawaiites have higher initial ${ }^{87} \mathrm{Sr} / 86 \mathrm{Sr}$ ratios than the tholeiite, which is the reverse of the Hawaiian volcanoes.

\section{Nintoku Seamount: Site $\mathbf{4 3 2}$}

The three flows of basalt recovered at Hole 432A on Nintoku Seamount are transitional between alkalic basalt and hawaiite. The major- and trace-element chemistry (Bence et al.; Kirkpatrick et al., this volume) indicates that the three flows are chemically similar, although Flow Unit 3 lacks the abundant plagioclase phenocrysts present in Flow Units 1 and 2. The mineral compositions of pyroxenes and feldspars indicate that these flows, like the Ōjin hawaiites, probably erupted during the post-caldera alkalic stage, although eruption during the post-erosional stage cannot be completely ruled out (Clague et al., this volume). The plagioclase phenocrysts in Flow Units 1 and 2 are reversely zoned, and contain abundant glass inclusions. They are probably xenocrysts inherited from a previous magma.

The REE patterns (Figure 11) for the three Nintoku flows are similar although not identical to those of Hawaiian alkalic basalts, and show progressive light REE enrichment. Flow Units 1 and 2 have parallel patterns, which suggests that they are probably related by crystal fractionation. Flow Units 1 and 3 have similar $\mathrm{Mg}$ values, but Flow Unit 1 has much higher abundances of the heavy REE than Flow Unit 3, suggesting that Flow Unit 1 was either generated by a smaller degree of partial melting or that its mantle source contained less garnet. Relative to the mid- and heavy REE, the light REE in Flow Units 1 and 2 are somewhat less enriched than those in Flow Unit 3. None of the analyzed flows shows either positive or negative Europium anomalies.

The ${ }^{87} \mathrm{Sr} /{ }^{86} \mathrm{Sr}$ ratios of the three Nintoku flows (Lanphere et,al., this volume) range from 0.70335 to 0.70347 , and have a weighted mean of 0.7034 . This ratio is between that of the hawaiites and that of the tholeiite 
TABLE 3

Average Chemical Analyses of Lavas Recovered on Leg $55^{\text {a }}$

\begin{tabular}{|c|c|c|c|c|c|c|c|c|}
\hline & \multicolumn{2}{|c|}{$\begin{array}{l}\text { Ojin Seamount } \\
(\text { Site } 430)\end{array}$} & \multirow{2}{*}{ 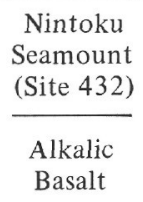 } & \multicolumn{5}{|c|}{$\begin{array}{l}\text { Suiko Seamount } \\
\text { (Site 433) }\end{array}$} \\
\hline & Hawaiite & Tholeiite & & $\begin{array}{c}\text { Alkalic } \\
\text { Basalt }\end{array}$ & $\begin{array}{l}\text { Picritic } \\
\text { Tholeiite }\end{array}$ & $\begin{array}{l}\text { Olivine } \\
\text { Tholeiite }\end{array}$ & $\begin{array}{c}\text { Plagioclase } \\
\text { Tholeiite }\end{array}$ & Tholeiite \\
\hline $\mathrm{SiO}_{2}$ & 47.8 & 47.7 & 46.3 & 46.5 & 43.3 & 45.7 & 47.2 & 46.6 \\
\hline $\mathrm{Al}_{2} \mathrm{O}_{3}$ & 15.9 & 15.3 & 16.5 & 14.3 & 9.0 & 13.4 & 14.6 & 14.3 \\
\hline $\mathrm{Fe}_{2} \mathrm{O}_{3}$ & 8.0 & 4.5 & 6.3 & 6.2 & 3.4 & 5.1 & 4.7 & 6.0 \\
\hline $\mathrm{FeO}$ & 4.1 & 7.9 & 6.2 & 7.8 & 8.8 & 7.1 & 7.2 & 6.6 \\
\hline $\mathrm{MgO}$ & 3.8 & 5.6 & 5.1 & 5.9 & 21.2 & 10.4 & 7.0 & 6.8 \\
\hline $\mathrm{CaO}$ & 6.6 & 11.0 & 8.6 & 9.3 & 5.0 & 8.9 & 10.1 & 9.9 \\
\hline $\mathrm{Na}_{2} \mathrm{O}$ & 4.3 & 3.0 & 3.6 & 3.4 & 1.2 & 2.4 & 2.8 & 2.9 \\
\hline $\mathrm{K}_{2} \mathrm{O}$ & 1.7 & 0.36 & 1.2 & 0.87 & 0.21 & 0.30 & 0.39 & 0.54 \\
\hline $\mathrm{H}_{2} \mathrm{O}^{+}$ & 1.2 & 0.39 & 1.5 & 1.1 & 4.6 & 2.3 & 1.1 & 1.2 \\
\hline $\mathrm{H}_{2} \mathrm{O}^{-}$ & 2.1 & 1.0 & 1.3 & 1.0 & 1.4 & 2.1 & 2.2 & 2.2 \\
\hline $\mathrm{TiO}_{2}$ & 2.9 & 2.8 & 2.7 & 3.0 & 1.2 & 2.2 & 2.3 & 2.5 \\
\hline $\mathrm{P}_{2} \mathrm{O}_{5}$ & 1.2 & 0.30 & 0.50 & 0.39 & 0.11 & 0.22 & 0.25 & 0.26 \\
\hline $\mathrm{MnO}$ & 0.10 & 0.18 & 0.15 & 0.19 & 0.16 & 0.17 & 0.14 & 0.16 \\
\hline $\mathrm{CO}_{2}$ & 0.06 & 0.04 & 0.10 & 0.05 & 0.05 & 0.10 & 0.05 & 0.32 \\
\hline Total & 99.8 & 100.1 & 100.0 & 100.0 & 99.6 & 100.4 & 100.0 & 100.3 \\
\hline
\end{tabular}

${ }^{a}$ Data from Kirkpatrick, et al., (this volume).

TABLE 4

Key Trace-Element Ratios for Lavas Recovered on Leg 55 a

\begin{tabular}{lccccc}
\hline & $\begin{array}{c}\bar{O} \text { Ojin Seamount } \\
\text { (Site 430) }\end{array}$ & $\begin{array}{c}\text { Nintoku Seamount } \\
\text { (Site 432) } \\
\text { Alkalic } \\
\text { Basalt }\end{array}$ & \multicolumn{2}{c}{$\begin{array}{c}\text { Suiko Seamount } \\
\text { (Site 433) }\end{array}$} \\
& Hawaiile & Basalt & Tholeiite \\
\hline $\mathrm{K} / \mathrm{Ba}$ & 40 & 32 & 29 & 38 & $25(10-40)$ \\
$\mathrm{K} / \mathrm{Rb}$ & 565 & 1360 & 530 & 542 & $\sim 900$ \\
$\mathrm{Zr} / \mathrm{Hf}$ & 42 & 39 & 45 & 41 & 39 \\
$\mathrm{Zr} / \mathrm{Nb}$ & 10.4 & 10.2 & 5.1 & 7.7 & 11.4 \\
$\mathrm{Th} / \mathrm{U}$ & 3.1 & 3.15 & 3.5 & 3.9 & 3.5 \\
$\mathrm{P} / \mathrm{Ce}$ & 111 & 92 & 95 & 83 & 95 \\
\hline
\end{tabular}

${ }^{\mathrm{a}}$ Data from Cambon et al.; Bence, et al.; Clague and Frey (all in this volume).

from Ōjin Seamount and, like them, is somewhat lower than the ratios observed for Hawaiian tholeiitic basalts. The value is, however, within the range observed for Hawaiian basalts. The $\mathrm{Zr} / \mathrm{Hf}$, $\mathrm{Th} / \mathrm{U}$, and $\mathrm{K} / \mathrm{Rb}$ ratios (Table 3) are nearly identical to those of the Ōjin hawaiites, but both $\mathrm{K} / \mathrm{Ba}$ and $\mathrm{Zr} / \mathrm{Nb}$ are distinctly lower in the Nintoku basalts.

\section{Suiko Seamount: Site $\mathbf{4 3 3}$}

The tholeiitic basalts from Suiko (Site 433) include picritic tholeiites (olivine phenocrysts $>15 \%$ ), olivine tholeiites (olivine phenocrysts $>5 \%$ ), plagioclase tholeiites (plagioclase phenocrysts $>5 \%$ ), and tholeiites (phenocrysts $<5 \%$ ). Geochemically, the tholeiitic basalts fall into two main groups (Kirkpatrick et al.; Bence et al.; Clague and Frey; this volume). One group has considerably higher concentrations of $\mathrm{TiO}_{2}, \mathrm{Zr}$, and light REE than the second group when the flows are compared at the same $\mathrm{Mg}$ or Ni values. Both groups contain flows that have experienced crystal accumulation to form picritic basalts, and flows that have apparently undergone vari- able degrees of low-pressure crystal fractionation or magma mixing. The two geochemical types are stratigraphically interlayered, as are the several petrographic types. The interlayering of chemical groups suggests that we may have sampled flows that originated from two distinct volcanoes, since lavas from individual Hawaiian volcanoes are usually very similar or evolve systematically (Wright, 1971). It is also possible that the lavas were erupted from a single volcano and that the magma composition alternated between high and low incompatible-element abundances. Such variations have not been observed in Hawaiian tholeiitic sequences, although transitional and alkalic basalts are interlayered on east Molokai (Beeson, 1976; Clague and Beeson, in press).

The Suiko alkalic basalt flows contain phenocrysts of plagioclase $\left(\mathrm{An}_{81-63}\right)$, clinopyroxene, and olivine $\left(\mathrm{Fo}_{82-81}\right)$. The compositions of the groundmass plagioclase and clinopyroxene are similar to those in Hawaiian alkalic basalts erupted during the alkalic stage (Clague, Fisk, and Bence, this volume). Flow Units 1 and 2 are correlated between Holes 433A, 433B, and 433C on the basis of mineralogic features. Flow Unit 1 contains clinopyroxene microphenocrysts with well-developed sector zoning, and Flow Unit 2 contains rare kink-banded olivine phenocrysts. The tholeiitic picrites contain olivine $\left(\mathrm{Fo}_{87-86}\right)$ phenocrysts with inclusions of high $-\mathrm{Zr}_{2} \mathrm{O}_{3}$ chromium spinel. The olivine tholeiites have less magnesian olivine, and the enclosed spinel contains less $\mathrm{Cr}_{2} \mathrm{O}_{3}$ and more $\mathrm{TiO}_{2}$. The groundmass pyroxene is generally low in calcium content $(\mathrm{Wo}=30-32 \%)$, and has a wide range of iron enrichment similar to that observed in Hawaiian tholeiitic basalts. At least three flows contain pigeonite, although the olivine-pigeonite reaction relations common in tholeiitic basalts were not observed. The crystallization sequence is phenocrysts of chromium spinel, ol- 

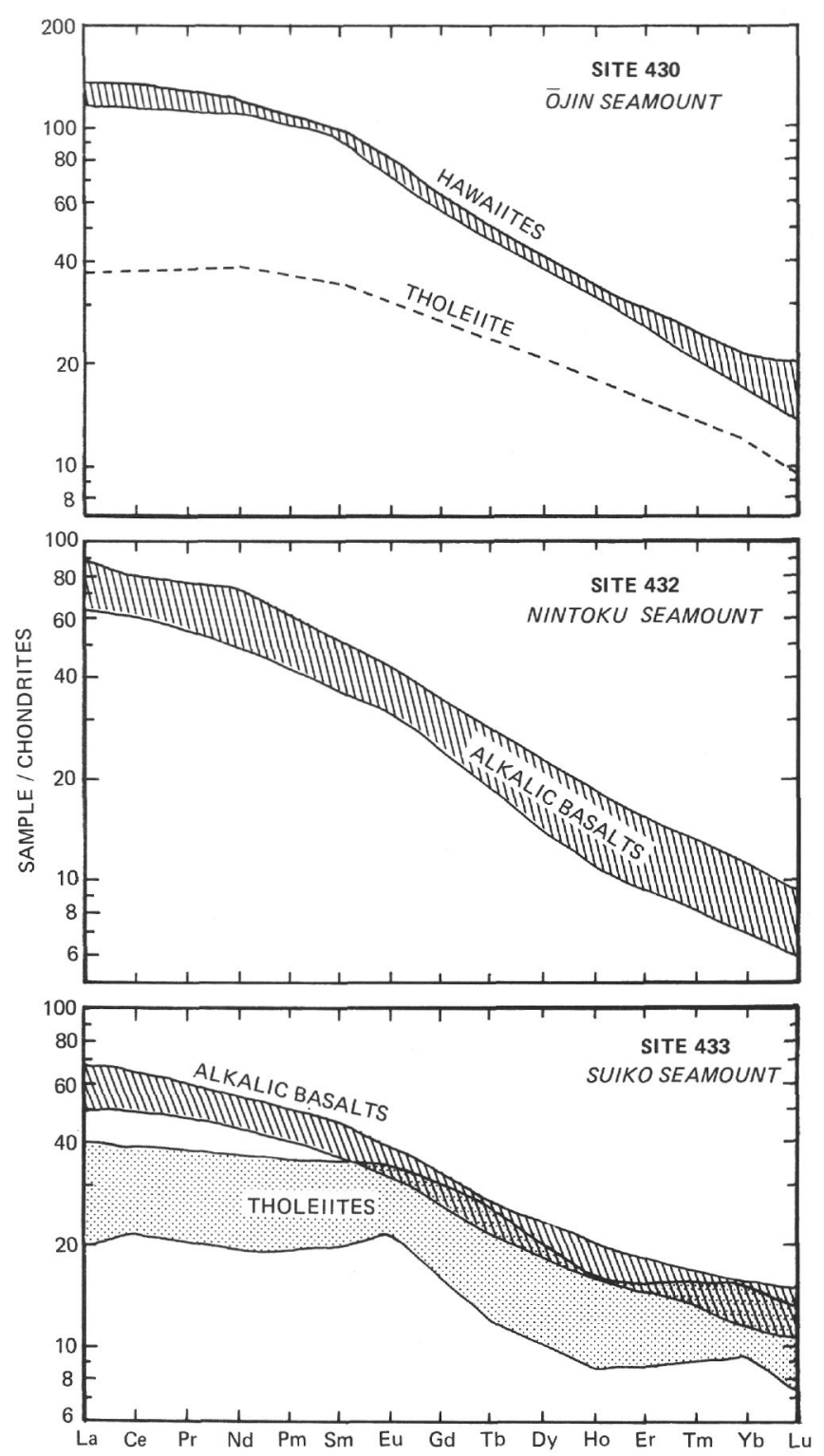

Figure 11. Chondrite-normalized REE abundances for basalt samples from Öjin, Nintoku, and Suiko seamounts. Data from Clague and Frey and from Bence et al. (all this volume).

ivine, plagioclase, and clinopyroxene, followed by groundmass plagioclase $\left(1180^{\circ} \mathrm{C}\right)$, clinopyroxene, and $\mathrm{Fe}-\mathrm{Ti}$ oxides $\left(1140^{\circ}-670^{\circ}\right)($ Clague, Fisk, and Bence, this volume).

The alkalic basalts from Suiko are enriched in the light REE, although the REE from La through Er are slightly less fractionated than Hawaiian alkalic basalts (Figure 11). The heavy REE have high abundances (11-15 $\times$ chrondrites), and the light REE are 52-68 $\times$ chrondrites. There are no Eu anomalies. The Suiko tholeiitic basalts all have distinctive REE patterns that are very flat from $\mathrm{La}$ to $\mathrm{Eu}$ and more strongly fractionated in the mid- to heavy-REE than the alkalic basalts. In the least fractionated basalts, the REE are 20-30 $\times$ chrondrites, while the heavy REE are 8-10 $\times$ chondrites. It is apparent that both high- and low-REE magmas are represented. They were probably generated by different percentages of partial melting of geochemically similar sources (Clague and Frey, this volume). Fractionation calculations based on incompatible trace elements suggest that the most differentiated lavas from each group represent less than 50 per cent residual liquid.

The ${ }^{87} \mathrm{Sr} / 86 \mathrm{Sr}$ ratios of the Suiko alkalic basalts range from 0.7029 to 0.7033 , and average 0.7031 . This mean is lower than any known Hawaiian alkalic basalt (Lanphere et al., this volume; Lanphere and Dalrymple, 1980). The Suiko tholeiitic basalts have slightly higher ${ }^{87} \mathrm{Sr} /{ }^{86} \mathrm{Sr}$ ratios than the alkalic basalts, but the range (0.70316-0.70336) is still lower than any analyzed Hawaiian tholeiite. The average for the Suiko alkalic basalts is 0.7032 , which compares with a value of 0.7033 for the single tholeiitic flow at Ōjin Seamount, 0.7036 for the two tholeiitic basalts from Kōkō Seamount, and 0.7032 for tholeiites from southern Kōkō Seamount. Some of the Suiko tholeiites have ${ }^{87} \mathrm{Sr} /{ }^{86} \mathrm{Sr}$ ratios that are not supported by their $\mathrm{Rb} / \mathrm{Sr}$ ratios, indicating that these tholeiites, and probably all of the Suiko tholeiites, were derived from a source depleted in $\mathrm{Rb}$ relative to $\mathrm{Sr}$ during one or more previous partial melting episodes.

The Suiko alkalic basalts have $\mathrm{K} / \mathrm{Ba}, \mathrm{K} / \mathrm{Rb}$, and $\mathrm{Zr} / \mathrm{Hf}$ ratios identical to those in the Ojin hawaiites (Table 4). Like those from Ōjin, the tholeiites from Suiko have higher $\mathrm{K} / \mathrm{Rb}$ ratios and slightly lower $\mathrm{Zr} / \mathrm{Hf}$ ratios than the overlying alkalic basalts. The high $\mathrm{K} / \mathrm{Rb}$ ratios for the tholeiitic basalts are consistent with the interpretation of the $\mathrm{Sr}$ isotopic data, and suggest that these basalts were derived from a previously depleted source region. The distinctive REE patterns for the tholeiites from both Ōjin and Suiko seamounts can be explained by a light-REE-depleted source and a small percentage of partial melting, although a variety of melting models using other REE abundance patterns can yield similar results (Leeman et al., in press).

\section{Variations Along The Chain}

It is significant for verification of the hot-spot hypothesis that tholeiitic basalts, similar to Hawaiian tholeiites but distinct from mid-ocean ridge basalts, have erupted along the entire chain. Tholeiitic basalts have been recovered at nine volcanoes along the Hawaiian Ridge west of Kauai and six volcanoes in the Emperor Seamounts. Alkalic basalts and their associated differentiated lavas, similar to those erupted in Hawaii, have been recovered from 10 volcanoes along the Hawaiian Ridge west of Kauai and eight volcanoes in the Emperor Seamounts (Clague, 1974; Dalrymple et al., 1974; Clague et al., 1975; Dalrymple and Garcia, this volume; Kirkpatrick et al., this volume). Most of the alkalic basalts contain pyroxenes similar to those found in Hawaiian alkalic basalts erupted during the alkalic stage of volcanism. Samples from two seamounts, however, contain pyroxenes that are most similar to alkalic basalts erupted during the Hawaiian post-erosional stage.

For the most part, there is little systematic variation in chemistry along the chain. The major-element chem- 
istry of the tholeiitic basalts (Table 5) does not appear to change with distance from Kilauea in any systematic way, although the lavas erupted from about 45 to $7 \mathrm{~m}$.y. ago (Daikakuji to Nihoa) have distinctly lower $\mathrm{Al}_{2} \mathrm{O}_{3}$ and generally higher $\mathrm{TiO}_{2}$ contents than tholeiitic basalts from the principal Hawaiian Islands and from Suiko Seamount (Kirkpatrick et al., this volume). There is also an inverse correlation between $\mathrm{CaO}$ and $\mathrm{Na}_{2} \mathrm{O}$ in the tholeiitic basalts, but the variation is not geographically systematic. Basalts with both high and low sodium contents have erupted throughout the history of the chain.

Hawaiian tholeiites have distinctive REE patterns with little to no light-REE fractionation and more extensive mid- to heavy-REE fractionation, and commonly have chrondrite normalized $\mathrm{La} \leq \mathrm{Ce}$. The REE patterns of the tholeiitic basalts recovered from Ōjin, Suiko, Nihoa, Necker, Midway and Kōkō volcanoes have these same features (Figure 12; Clague and Frey, this volume), and resemble Mauna Loa tholeiites (Leeman et al., in press). Other tholeiites recovered from La Perouse Pinnacles and Daikakuji Seamount have more fractionated light REE, and resemble Kilauea tholeiites. It is apparent that the source region for Hawaiian-Emperor volcanism has had very similar REE characteristics for the last 65 m.y. Computer modeling shows that these REE patterns can be generated by small degrees of partial melting of a previously depleted source region, by larger percentages of partial melting of an undepleted source leaving residual garnet, or by partial melt- ing of a light-REE-enriched source with no garnet in the residuum (Clague and Frey, this volume).

The $\mathrm{Sr}$ isotopic data (Lanphere et al., this volume) provide the only conclusive evidence that the source region for Hawaiian-Emperor tholeiites has changed systematically through time. The ${ }^{87} \mathrm{Sr} / 86 \mathrm{Sr}$ ratio of the tholeiites increases from about 0.7033 at Suiko Seamount (65 m.y. ago) to about 0.7037 at the Hawaiian-Emperor bend (Figure 13). For the past $43 \mathrm{~m} . \mathrm{y}$., the ${ }^{87} \mathrm{Sr} / 86 \mathrm{Sr}$ ratio in the tholeiites has remained essentially constant, though there is a range of values. Lanphere et al. (this volume) have suggested that the systematic change from Suiko to the bend may be related to distance from the Kula Ridge, and that if the trend is extrapolated northward, a seamount that formed on the Kula Ridge would have generated lava with ${ }^{87} \mathrm{Sr} /{ }^{86} \mathrm{Sr}$ values similar to those found in Iceland, where a hot spot is positioned on an active ridge.

The trace-element data suggest that both the tholeiitic basalts and the alkalic basalts erupted during the alkalic stage of volcanism are derived from different source regions, but that these sources have been of relatively constant composition through time. For example, the $\mathrm{K} / \mathrm{Ba}$ ratio of alkalic basalts erupted during the alkalic stage at Suiko, Ōjin, Kōkō, Midway, E. Molokai, and Hualalai are the same (Clague, 1974; Dalrymple et al., 1977; Clague and Beeson, in press; Bence et al., this volume; Clague, unpublished data). The tholeiitic basalts (Kauai, Niihau, E. Molokai, Ōjin, Suiko) generally have

TABLE 5

Calculated Parental Tholeiitic Basalts for Volcanoes Along the Hawaiian-Emperor Chain ${ }^{\mathrm{a}}$

\begin{tabular}{|c|c|c|c|c|c|c|c|c|c|c|c|c|c|}
\hline & Kilauea & $\begin{array}{l}\text { Mauna } \\
\text { Loa }\end{array}$ & $\begin{array}{l}\text { Mauna } \\
\text { Kea }\end{array}$ & Kohala & Haleakala & $\begin{array}{l}\text { W. } \\
\text { Maui }\end{array}$ & Lanai & $\underset{\text { Molokai }}{\text { E. }}$ & $\begin{array}{c}\text { W. } \\
\text { Molokai }\end{array}$ & Koolau & $\begin{array}{l}\text { Waianae } \\
\text { (Upper) }\end{array}$ & $\begin{array}{l}\text { Waianae } \\
\text { (Lower) }\end{array}$ & Kauai \\
\hline $\mathrm{SiO}_{2}$ & 48.9 & 50.5 & 46.4 & 48.2 & 49.7 & 47.3 & 49.0 & 46.4 & 49.2 & 51.5 & 46.9 & 47.9 & 48.4 \\
\hline $\mathrm{Al}_{2} \mathrm{O}_{3}$ & 12.1 & 12.2 & 12.8 & 13.5 & 13.25 & 12.6 & 12.8 & 12.9 & 11.8 & 13.2 & 13.4 & 14.1 & 12.5 \\
\hline $\mathrm{FeO}$ & 11.4 & 11.0 & 12.3 & 11.8 & 10.9 & 12.2 & 11.0 & 12.4 & 11.9 & 10.4 & 11.9 & 11.2 & 11.9 \\
\hline $\mathrm{MgO}$ & 12.7 & 12.3 & 13.6 & 13.1 & 12.1 & 13.7 & 12.3 & 13.8 & 13.2 & 11.7 & 13.2 & 12.5 & 13.3 \\
\hline $\mathrm{CaO}$ & 9.7 & 9.2 & 9.9 & 9.4 & 9.6 & 9.8 & 8.8 & 9.7 & 8.9 & 8.3 & 9.1 & 9.6 & 9.2 \\
\hline $\mathrm{Na}_{2} \mathrm{O}$ & 1.99 & 1.98 & 1.82 & 1.62 & 1.76 & 1.66 & 2.13 & 1.89 & 2.42 & 2.47 & 2.07 & 1.86 & 1.93 \\
\hline $\mathrm{K}_{2} \mathrm{O}$ & 0.44 & 0.36 & 0.28 & 0.10 & 0.33 & 0.23 & 0.11 & 0.20 & 0.18 & 0.27 & 0.53 & 0.26 & 0.30 \\
\hline $\mathrm{TiO}_{2}$ & 2.34 & 1.85 & 2.40 & 1.93 & 2.01 & 2.14 & 1.66 & 2.22 & 2.08 & 1.68 & 2.46 & 2.20 & 2.06 \\
\hline $\mathrm{P}_{2} \mathrm{O}_{5}$ & 0.22 & 0.21 & 0.23 & 0.20 & 0.13 & 0.20 & 0.18 & 0.25 & - & 0.22 & 0.35 & 0.25 & 0.23 \\
\hline $\mathrm{MnO}$ & 0.17 & 0.16 & 0.17 & 0.18 & 0.18 & 0.17 & 0.14 & 0.18 & 0.19 & 0.15 & 0.15 & 0.17 & 0.17 \\
\hline
\end{tabular}

\begin{tabular}{|c|c|c|c|c|c|c|c|c|c|c|c|c|}
\hline & Niihau & Nihoa & $\# 20$ & $\# 21$ & Necker & $\begin{array}{c}\text { La } \\
\text { Perouse }\end{array}$ & Northampton $\mathrm{c}$ & Pioneer & $\# 63$ & Daikakuji & $\begin{array}{c}\text { Suiko } \\
\text { High } \mathrm{TiO}_{2}\end{array}$ & $\begin{array}{c}\text { Suiko } \\
\text { Low } \mathrm{TiO}_{2}\end{array}$ \\
\hline $\mathrm{SiO}_{2}$ & 48.4 & 47.4 & 46.85 & 47.1 & 47.15 & 47.5 & 48.7 & 48.15 & 46.5 & 49.7 & 47.6 & 47.9 \\
\hline $\mathrm{Al}_{2} \mathrm{O}_{3}$ & 12.1 & 11.5 & 11.2 & 11.3 & 11.1 & 11.7 & 11.4 & 11.2 & 11.4 & 11.5 & 12.7 & 13.0 \\
\hline $\mathrm{FeO}$ & 12.1 & 12.4 & 13.6 & 12.4 & 12.8 & 11.8 & 11.7 & 11.9 & 12.8 & 11.5 & 12.3 & 11.9 \\
\hline $\mathrm{MgO}$ & 12.6 & 13.8 & 14.0 & 13.8 & 14.1 & 13.1 & 13.0 & 13.3 & 14.2 & 12.9 & 13.7 & 13.2 \\
\hline $\mathrm{CaO}$ & 8.1 & 9.4 & 9.6 & 9.2 & 9.8 & 10.7 & 10.05 & 9.8 & 8.4 & 9.05 & 8.7 & 9.3 \\
\hline $\mathrm{Na}_{2} \mathrm{O}$ & 2.28 & 1.77 & 2.06 & 2.25 & 1.59 & 1.82 & 2.00 & 2.20 & 2.75 & 2.08 & 2.26 & 2.26 \\
\hline $\mathrm{K}_{2} \mathrm{O}$ & 0.49 & 0.26 & 0.24 & 0.64 & 0.38 & 0.39 & 0.32 & 0.67 & 0.56 & 0.43 & 0.28 & 0.14 \\
\hline $\mathrm{TiO}_{2}$ & 2.49 & 2.59 & 2.97 & 2.72 & 2.47 & 2.44 & 2.26 & 2.36 & 2.92 & 2.32 & 2.10 & 1.86 \\
\hline $\mathrm{P}_{2} \mathrm{O}_{5}$ & 0.31 & $(0.70)^{b}$ & 0.28 & 0.35 & 0.36 & 0.34 & 0.23 & 0.17 & 0.26 & 0.36 & 0.22 & 0.16 \\
\hline $\mathrm{MnO}$ & 0.16 & 0.15 & 0.15 & 0.15 & 0.17 & 0.20 & 0.16 & 0.14 & 0.17 & 0.16 & 0.18 & 0.18 \\
\hline
\end{tabular}

aData are arranged as a function of distance from Kilauea. Volcano numbers of Bargar et al. (1974) are used for unnamed seamounts. Compositions are averages of dry reduced, normalized analyses of tholeiitic basalts with $\mathrm{MgO}=8 \%$. Olivine (Fo86) was added or subtracted so that $100 \mathrm{Mg} /(\mathrm{Mg}+0.85 \mathrm{Fe})=70$. From Kirkpatrick et al. (this volume).

brobably phosphatized.

${ }^{\mathrm{C}}$ Data from M.O. Garcia (personal communication, 1978). 


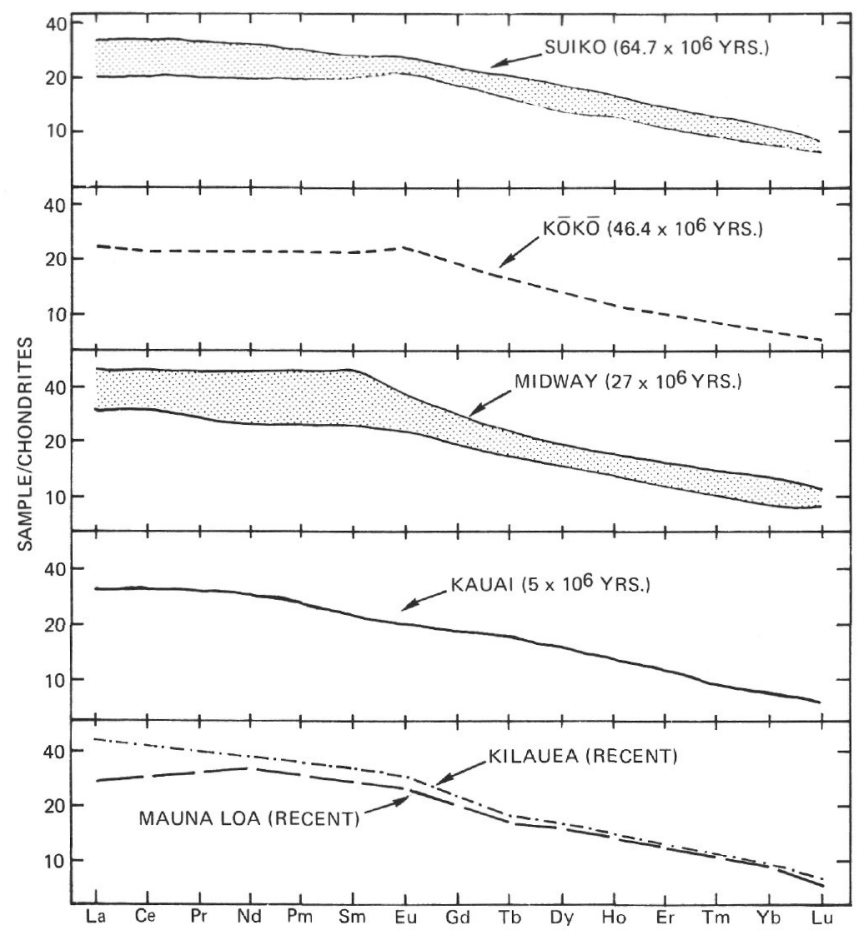

Figure 12. Chondrite-normalized REE abundances in tholeitic basalts for selected volcanoes along the Hawaiian-Emperor chain. From Clague and Frey (this volume).

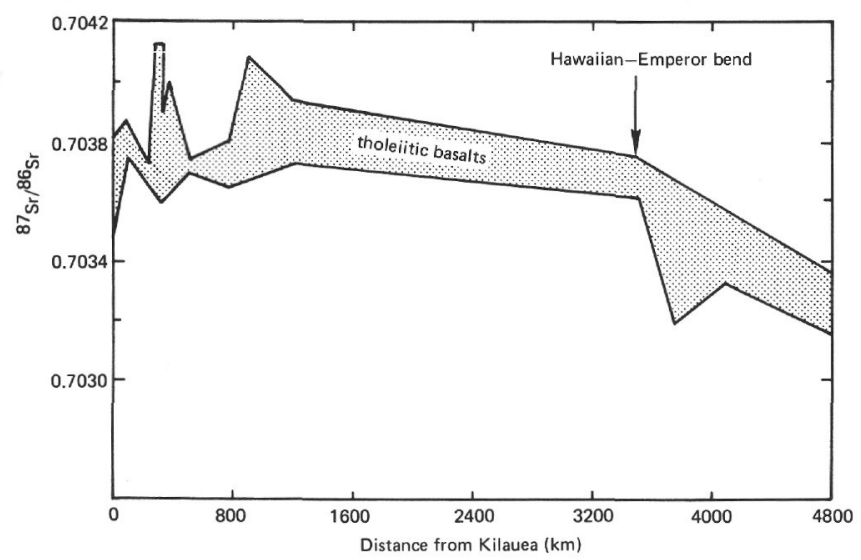

Figure 13. The range of ${ }^{87} \mathrm{Sr} / 86 \mathrm{Sr}$ values for tholeiitic basalts as a function of distance from Kilauea volcano. From Lanphere et al. (this volume).

$\mathrm{K} / \mathrm{Ba}$ ratios that range from only about 25 to 30 (Clague and Frey, this volume; Clague and Beeson, in press; Clague, unpublished data). Other key trace-element ratios also appear to be relatively constant among the tholeiitic or alkalic suites erupted along the chain. Drilling during Leg 55 apparently recovered no post-erosional alkalic basalts, but elsewhere along the chain this suite of rocks shows clear evidence of chemical variation through time. For example, the post-erosional alkalic rocks from $\mathrm{Oa}-$ hu, Kauai, and Niihau have similar trace-element ratios (e.g., $\mathrm{K} / \mathrm{Ba}=9-22$ ), whereas post-erosional lavas dredged near Midway Islands have $\mathrm{K} / \mathrm{Ba}=40-100$ (Clague et al., 1977; Clague, 1974; Clague, unpublished data). This suggests that the source region for the post-erosional alkalic basalts may have changed through time.

It is interesting to speculate on the location of the Hawaiian-Emperor hot-spot source region. This source has produced about $10^{6} \mathrm{~km}^{3}$ of tholeiitic basalt with similar geochemical characteristics during the past 65 m.y. If we arbitrarily assume approximately 20 per cent partial melting of the source region, then $5 \times 10^{6} \mathrm{~km}^{3}$ of geochemically similar mantle source is required. The vast volume of material involved is itself a constraint on the possible source locations. There are three potential locations of this source material: the deep mantle, the asthenosphere, and the lower lithosphere. The geochemical data along the chain suggest that the source region is broadly homogeneous but it must have smallscale heterogeneities to account for the variations observed between adjacent volcanoes. Present mantle convection models (Richter and Ribe, in press; McKenzie, in press) do not allow long-term preservation of a largescale geochemical anomaly in the asthenosphere such as that required to generate the Hawaiian-Emperor lavas. The deep mantle is a possible source, although it is not clear how the small-scale heterogeneities required could persist for such long periods (Hoffman and Hart, 1978) if the mantle is convecting. The lower lithosphere is a potential source if we assume that the vast bulk of the asthenosphere that accretes to the base of the oceanic lithosphere is geochemically distinct from the mid-ocean ridge basalt (MORB) source or residuum. The upper lithosphere almost certainly has geochemical characteristics similar to MORB, since at least some of it represents the residuum left after the generation of MORB. If the lower lithosphere is a geochemically appropriate source region, the volume of basalt generated would require partial melting of a cylinder $50 \mathrm{~km}$ in diameter and $50 \mathrm{~km}$ high underlying each volcano. This is a severe constraint; it requires partial melting of roughly the entire lithosphere beneath the chain. Detrick and Crough (1978) have presented convincing arguments that hot spots are thermal anomalies. Their model of the heating, thinning, and uplift of the lithosphere above hot spots suggests that the magmas making up the volcanoes could result from partial melting of the lower lithosphere by heating and decompression.

\section{Post-Volcanic Subsidence History}

The cores recovered from Ōjin, Yōmei, Nintoku, and Suiko seamounts record a long history of volcanic eruption followed by weathering, erosion, subsidence, and marine sedimentation. These volcanoes, which once rose above the sea, have now subsided as much as $2 \mathrm{~km}$ beneath sea level. Seismic reflection data show that faulting and folding of the sediments occurred as the seamounts subsided. The sequence of events recorded in the Leg 55 cores allows us to determine the history of these volcanoes and to show that they once formed volcanic islands that were very similar to the Hawaiian Islands of today. This history not only indicates what 
happened to these ancient volcanoes as they drifted away from the hot spot and became extinct, but it allows us to predict with near certainty the eventual fate of the Hawaiian Islands.

For purposes of discussion, we have divided the postvolcanic history into three stages: subaerial, shallowwater, and deep-water or bathyal.

\section{Subaerial Stage}

The evidence that Ōjin, Nintoku, and Suiko seamounts were once volcanic islands is both abundant and decisive. The basalt flows drilled at Sites 430, 432, and 433 have several physical and chemical characteristics unique to subaerial flows. The titanomagnetite of most of the flows has undergone high-temperature oxidation and exsolution of ilmenite (Kono, this volume: Kono, Clague, and Larson, this volume). This is common in subaerial lavas, but rare in submarine lavas, where the titanomagnetite is usually oxidized at low temperature to titanomaghemite. Many of the flows have vesicular tops; the size and abundance of the vesicles increase toward the top. Near flow tops, vesicles frequently account for more than 20 per cent of the rock by volume, and are often much larger than $1 \mathrm{~mm}$, both of which indicate extrusion in air or perhaps very shallow water (Moore, 1965). Vesicular flow tops are commonly oxidized to colors ranging from bright red to brown, a phenomenon that does not occur in the submarine environment but requires subaerial exposure. Section 21-2 from Hole $433 \mathrm{C}$ contains a layer of pumice lapilli that is oxidized red and brown, and is now cemented with calcite; it appears to be an airfall deposit. There is no evidence in any of the flows of pillow structure or of any other features that might indicate submarine eruption.

Parts of oxidized soil zones were recovered in the cores at both Ōjin and Nintoku seamounts. The soil from Ōjin occurs at the base of hawaiite Flow Unit 3 in Section 6-3 of Hole 430A; it was not studied in detail. The Nintoku soil occurs at the base of Flow Unit 2 in Hole 432A, Section 2-4, and has been studied by Karpoff (this volume). The upper, most well developed part of the soil consists of 62 per cent kaolinite and halloysite, 28 per cent $\mathrm{Fe}-\mathrm{Ti}$ oxides, and 10 per cent silicates. Karpoff concludes that the soil developed by weathering of a basaltic ash in a subtropical environment, that it is immature, and that its development was halted by emplacement of the overlying flow.

Many of the basalt flows at Site 433 contain carbonate veins whose oxygen and carbon isotope compositions have been studied by McKenzie (this volume). Deposition of these carbonates probably began while the basalts were above sea level, and proceeded as they passed through the shallow-water stage and into the deep marine environment. The high-Mg calcite rosette with negative $\delta^{13} \mathrm{C}$ and $\delta^{18} \mathrm{O}$ ratios (Figure 14) is, in particular, a likely candidate for a fresh-water origin. The fibrous carbonates with negative $\delta^{13} \mathrm{C}$ ratios were probably formed in the shallow subtidal to supratidal environment, where $\mathrm{CO}_{2}$ depleted in ${ }^{13} \mathrm{C}$ was readily available from fresh-water run-off or near-shore organic activity.

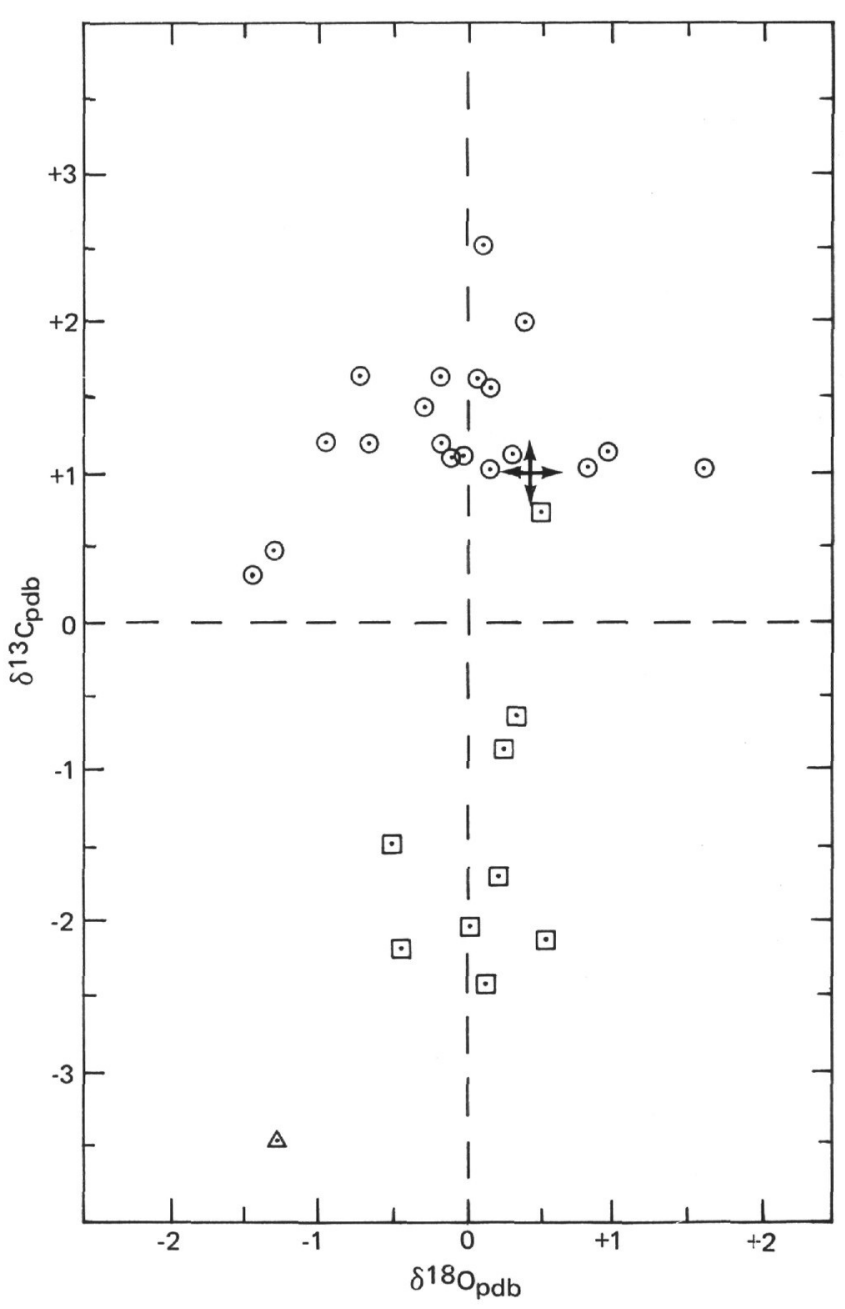

Figure $14 .{ }^{18} \mathrm{O}$ versus ${ }^{13} \mathrm{C}$ ratios for interbasaltic and overlying biogenic carbonate sediments from Suiko Seamount (Hole 433C). Symbols: ( $\square$ ) fibrous carbonates, $(\odot)$ blocky or dog-toothed carbonates, $(\triangle)$ high-Mg calcite rosette, and (\$) average biogenic carbonate sediment. From McKenzie (this volume).

Other evidence suggesting a subaerial or near-sealevel history for these seamounts includes carbonate sands and wave-rounded volcanic pebbles that overly basalt flows at Ōjin and Nintoku, and a possible beach sand composed of mixed biogenic carbonate debris and volcanic detritus between Flow Units 1 and 2 at Suiko. These deposits suggest the presence of beaches and that the seamounts once stood at sea level. Similar evidence was found at Kōkō seamount in the southern Emperor Seamounts, where dredging recovered numerous beachrounded pebbles (Davies et al., 1971). At Yōmei Seamount, the seismic reflection profiles (Greene et al., this volume; Dalrymple, Greene, Ruppel, Bear, and Clague, this volume) show volcanic peaks jutting through the sediments. The drilling results at this site show that these sediments are of shallow-water origin, indicating that the volcanic peaks must once have stood above sea level. 


\section{Shallow-Water Stage}

After cessation of volcanism, the seamounts underwent a period of subaerial and shallow-water marine erosion, and deposition of shallow-water biogenic carbonate sediments, which eventually capped most or all of each volcano. If the Island of Hawaii is typical (Moore, 1965), subsidence probably began in response to the excess load on the crust when the volcano was still active, and may have continued to the present. Also by analogy with the main Hawaiian Islands, the development of carbonate reef or bank deposits probably began before the volcanoes became extinct. As subsidence and erosion continued, the tops of the seamounts were eventually flattened and volcanic rocks gradually gave way to the organic carbonates.

As discussed previously, the biogenic carbonate sediments found on Ōjin, Nintoku, and Suiko clearly represent the Bryozoan-Algal facies of Schlanger and Konishi (1975), indicating deposition in waters somewhat cooler than presently found at the latitude of Hawaii. The absence of corals and the dominance of the less productive bryozoans may account for the relatively thin carbonate caps, which reach a maximum thickness of only 100 meters on Suiko. Although coral debris is rare in the recovered cores, its absence may be partly a result of local variations and the locations of the drill holes. Seismic data (Greene, this volume; Dalrymple, Greene, Ruppel, Bear, and Clague, this volume) seem to show the presence of acoustically opaque structures inferred to be discontinuous reefs that provided at least minimum protection to a lagoonal environment.

The microfossil assemblages in the carbonate sediments at Ōjin, Nintoku, and Suiko are dominated by endemic, shallow-water forms, and include primarily foraminifers, ostracodes, bryozoans, calcareous red algae, and spirorbids (Butt, this volume; Hagn et al., this volume). Even though corals are apparently rare, the abundant larger foraminifers, some of the planktonic foraminifers, such as keeled globorotaliids, and the broad attachment base of the spirorbids, provide evidence of warm tropical to subtropical waters.

The mixed volcanic and carbonate sand immediately above the basalt on Ōjin Seamount (core 430A-4) contains ooliths, which suggests a littoral environment with depths of 5 meters or less. Upward in the cores at Site 430 , there is evidence that the water depths increased; this indicates that carbonate deposition was not keeping pace with subsidence. The central depression at Ōjin (Greene et al., this volume) gradually evolved into a lower energy lagoonal basin with water depths of between 5 and 50 meters. Bryozoans, ostracodes, echinoid spines, fish teeth, and serpulids all indicate the presence of a nearby shore, but benthic foraminifers such as species of Cibicides, Discorbis, Lenticulina, and the miliolids suggest a slightly deeper (but $<50 \mathrm{~m}$ ) inner shelf environment (Figure 15; Butt, this volume; Hagn et al., this volume). The shallow-water stage did not last long at Ōjin, and the carbonate buildup had ceased by the late Paleocene or early Eocene, probably as a result of continued subsidence.

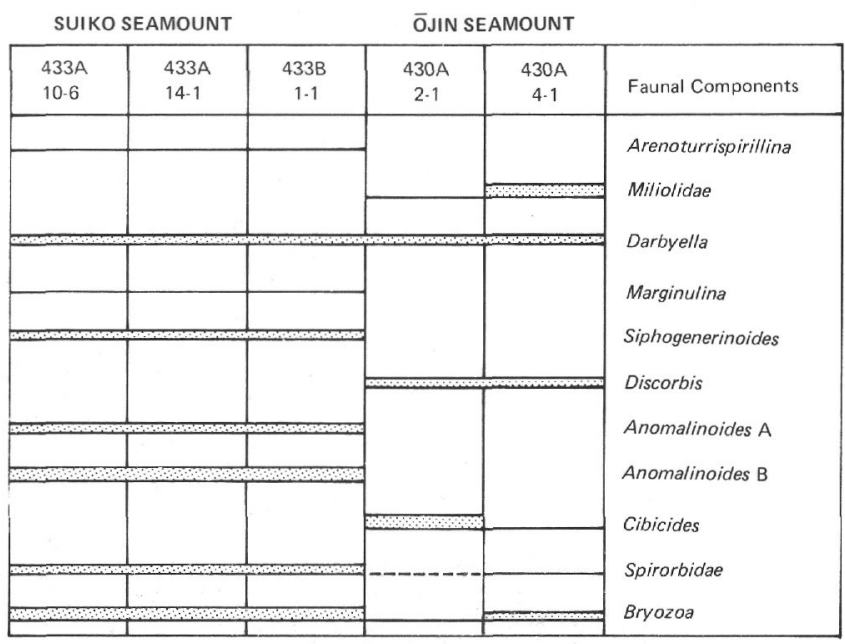

Figure 15. Relative abundances of Paleocene reef fossils at Ōjin and Suiko seamounts. After Hagn et al. (this volume).

The volcanic surface at Nintoku is an extensive and well-developed platform covered with shallow-water carbonate and volcanogenic sediments pierced at the seamount's crest by erosional volcanic knobs. Detritus from the seamount supplied to the fringes of the island produced extensive depositional terraces, and Site 432 is on one of these terraces at the northern edge of the seamount. Sediment recovery from Nintoku was very poor, and the holes did not penetrate lagoonal deposits, so the shallow-water history is sketchy. The biota in the mixed carbonate and volcanic detritus above basalt, however, is similar to that found in the upper part of the carbonate section at Ōjin. Bryozoans, ostracodes, echinoid spines, and serpulids suggest a near-shore reef or bank environment. The benthic foraminifers of the genera Discorbis, Cibicides, and Lenticulina suggest a shelf depth of less than 50 meters; the larger foraminifers and keeled globorotaliids suggest warm waters (Butt, this volume). Seismic evidence (Greene et al.,this volume) shows that the shallow-water sediments reach a maximum thickness of 200 meters. As at Ōjin, the shallowwater stage was neither extensive nor of long duration, and carbonate sedimentation had ceased by late Paleocene time.

Very little sediment was recovered at Yōmei Seamount, and basement was not reached, but seismic profiles (Greene et al., this volume; Dalrymple et al., this volume) show central erosional volcanic peaks surrounded by lagoonal deposits which are bounded by patchy reefs or banks. Extensive terrace deposits surround the lagoonal and reef sediments. The oldest sediment recovered is carbonate sand containing Eocene microfossils. Although the history of Yōmei cannot be reconstructed in detail, the available data suggest that this seamount had a shallow-water history similar to the other seamounts drilled on Leg 55.

The top of Suiko Seamount is an extensive, gently domed volcanic platform capped by reef-flat and lagoonal sediments, patchy fringing reefs or banks, and 
depositional terrace deposits. The lagoonal sediments reach a thickness of 500 meters (Greene et al., this volume). Site 433 is situated in the lagoonal deposits, and drilling there penetrated 110 meters of Paleocene carbonate sand and sandy mud with algal nodules above the basalt. The faunal assemblages in the carbonate sediments at Site 433 indicate that a variety of shallowwater conditions existed within the lagoon. In addition to foraminifers, ostracodes, bryozoans, calcareous red algae, and abundant spirorbids (Figure 15), the sediments contain parts of thalassinoid shrimp, echinoid plates and spines, and fish teeth (Hagn et al., this volume). The foraminifers consist primarily of species of Arenoturrispirillina, lagenids, polymorphinids, and simple rotalid forms; miliolids are absent. The tests are very well preserved, and broken or worn tests are absent. The finely sculptured zoecias of the bryozoans are also basically undamaged. This suggests a relatively low energy environment. In contrast, the ostracodes have thick-walled and well-ornamented carapaces, suggesting a nearby high-energy environment with water depths of less than 10 meters. The spirorbids indicate depths of less than 50 meters; the thalassinoid shrimp typically inhabit waters between 5 and 30 meters. The faunas thus indicate that deposition took place in water depths between 5 and 30 meters, and that the energy environment within the lagoon varied locally from high or moderate to low. The persistence of these assemblages throughout the 110 meters of carbonate sediments shows that the environment persisted for several million years (Butt, this volume) as the carbonate accumulation, which proceeded at about $1.8 \mathrm{~cm} / 1000$ years, kept pace with subsidence of the seamount.

The data indicate that the shallow-water stage at Ōjin, Nintoku, and Suiko seamounts was short-lived. Pelagic foraminifers (Hagn et al., this volume; Butt, this volume) and coccoliths (Takayama, this volume) at Ojin show that the oldest sediments above basalt are upper Paleocene, as is most of the 60 meters of carbonate sediment penetrated at the site. Coccoliths indicate that the calcareous and volcanic pebbly mudstone in the uppermost part of the section are upper Eocene (Figure $3)$. The sediments immediately above basalt at Nintoku are Paleocene, and upper Paleocene to lower Eocene (?) planktonic foraminifers occur in the volcanic sand only a few meters below the top of the section (Butt, this volume). At Suiko Seamount, middle Paleocene coccoliths and middle to lower Paleocene planktonic foraminifers are present above the basalt (Takayama, this volume; Butt, this volume; Hagn et al., this volume). The youngest shallow-water carbonate sediments occur at a sub-bottom depth of about 52 meters and are upper Paleocene. Thus, shallow-water conditions favorable to the growth of organisms of the Bryozoan-Algal facies persisted for only a few million years at most at each of these seamounts.

Carbonate reef and bank growth was probably terminated by subsidence and not by either northward movement of the Pacific plate, as postulated by Greene et al., (1978), or global cooling. Figure 7 shows that the temperature of the surface waters at Suiko, for example, probably had cooled by only about a degree as a result of northward motion of the seamount by middle to late Eocene. The same would be true for Nintoku and Ojjin. In addition, the drastic worldwide cooling of the oceans in the late Eocene to early Oligocene occurred after the shallow-water carbonate buildup at Suiko had ceased. Thus, it seems likely that the organisms of the Bryozoan-Algal facies, which are not very productive compared with those of the Coral-Algal facies (Schlanger and Konishi, 1975), simply could not keep pace with subsidence.

\section{Bathyal Stage}

At Ōjin, Yōmei, Nintoku, and Suiko, a hiatus representing a significant period of non-accumulation of sediment occurs above the shallow-water carbonate section (Figure 3). At Ōjin, a few meters of Quaternary foraminiferal sand directly overlies the shallow-water carbonates; the Eocene through Pliocene section is missing. At Yōmei, a few meters of lower Quaternary sand and fine gravel, primarily $\mathrm{Fe}-\mathrm{Mn}$ oxides, authigenic zeolites, and carbonates, overlies Paleocene calcareous siltstone and mudstone; as at Ōjin, the Eocene through the Pliocene are not represented. At the Nintoku site, the uppermost five meters consists of foraminiferal ooze and sand, directly underlain in Section 1-4 by Paleocene calcareous and volcanic sand. Again, Eocene through Pliocene sediments are absent. At Suiko, the Paleocene shallow-water carbonates are overlain by 51 meters of pelagic sediments ranging from lower Miocene to Quaternary; Eocene and Oligocene sediments are missing.

Apparently, after the tops of the seamounts had subsided to depths below 100 meters or so, where the shallow-water organisms could no longer survive, pelagic sediments did not accumulate, because of strong currents across the tops of the seamounts. The exception was at Suiko, where local faulting formed small faultbounded basins that grew as sediments accumulated (Figure 16). These vertical faults are probably the result of gravitational effects and adjustment of the seamount to subsidence (Greene et al., this volume). Site 433 is in one of these small basins that apparently began to form and to accumulate sediments in the early Miocene. The basin may not have been well developed then, however, for only a few centimeters of lower Miocene sediment is present. The lower Miocene is directly overlain by uppermost Miocene sediments. From late Miocene to early Pliocene time, sediment accumulation was more or less continuous at an average rate of about $3-5 \mathrm{~cm} / 1000$ years (Figure 17). Since the early Pliocene, the rate has been about an order of magnitude slower. The hiatuses and changes in sediment accumulation rate during the Neogene, however, may have been more a function of the rate of basin growth than of sediment supply.

The benthic foraminifers in the pelagic sediments recovered from Suiko should be excellent indicators of oceanic depths, and thus record the subsidence history 


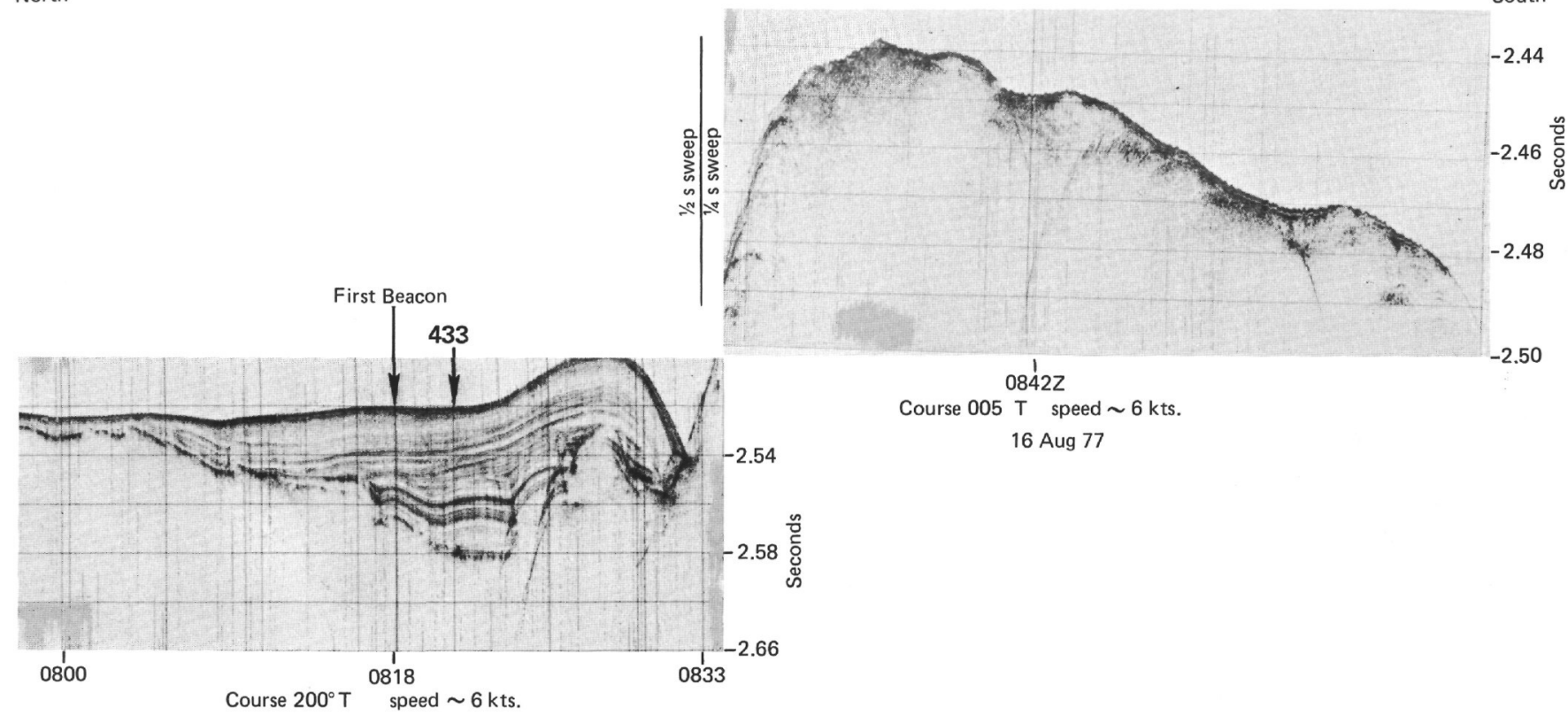

Figure 16. Glomar Challenger 3.5-kHz seismic profile across Site 433 on Suiko Seamount, showing the fault-bounded basin filled with pelagic sediments.

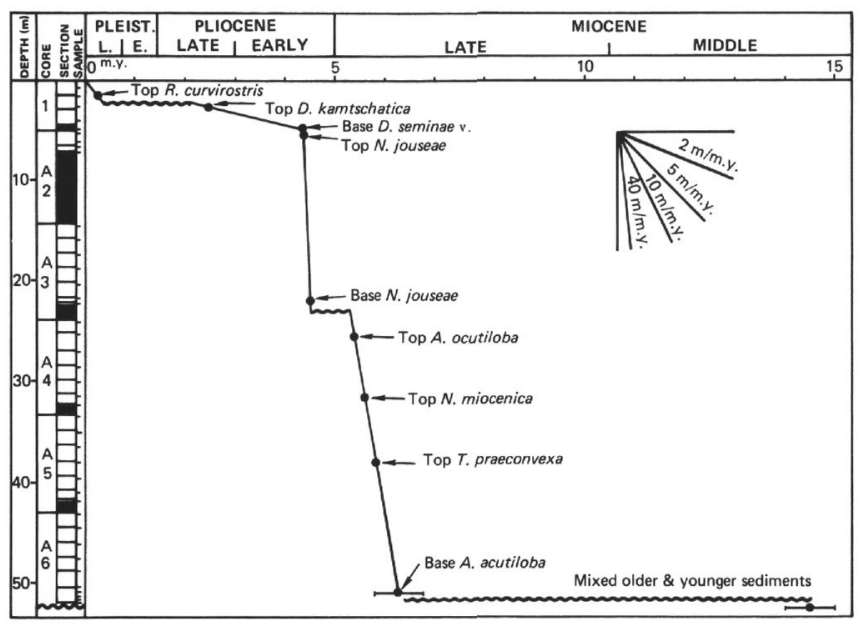

Figure 17. Sediment accumulation rates for the Neogene sediments at Site 433. Black areas in the column show where no core was recovered. From Koizumi (this volume).

of the seamounts. Butt (this volume) has identified four main benthic assemblages in the foraminifers at Site 433. These include the following:

I- A Paleocene association indicating an inner shelf environment with water depths of about 25 to 30 meters.

II- A lower Miocene upper middle bathyal association suggesting a depth of 1000 meters or more.

III- An upper Miocene-Pliocene lower middle bathyal assemblage indicating depths between 1000 and 1500 meters.
IV- A Pleistocene upper lower bathyal assemblage suggesting a depth greater than 1500 meters and about equal to that of the present depth of the seamount.

The oldest shallow-water carbonate sediments at Site 433 are now 2027 meters below sea level, which requires an average rate of subsidence over the last $65 \mathrm{~m}$.y. of about $3.1 \mathrm{~cm} / 1000$ years. If the deepest subaerial flow recovered is used as a datum $(2412 \mathrm{~m})$, the average rate is $3.7 \mathrm{~cm} / 1000$ years. The benthic foraminiferal data suggest, however, that subsidence may have been somewhat slower during the Paleogene and more rapid during the Neogene (Figure 18). Although the Eocene-Oligocene

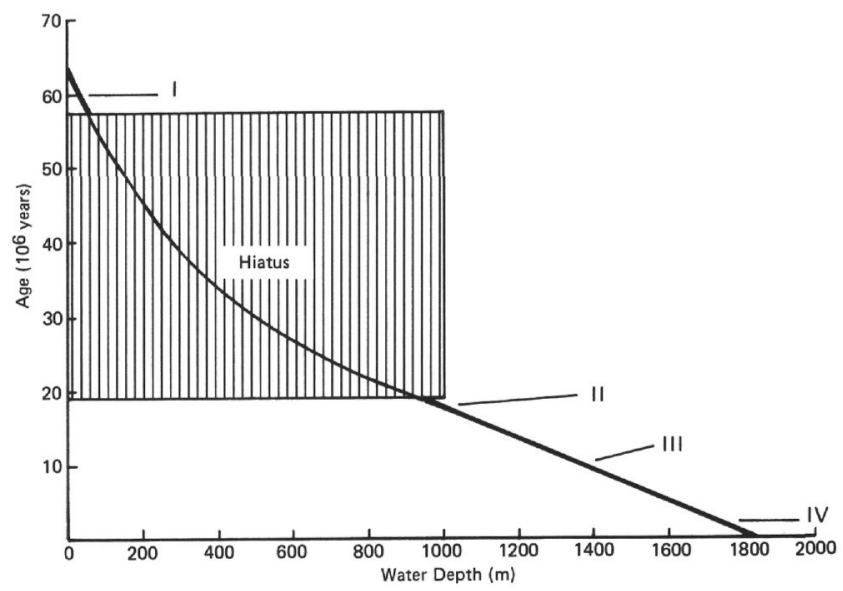

Figure 18. Subsidence curve for Suiko Seamount, using paleodepths based on benthic foraminiferal assemblages I through IV. See text. From Butt (this volume). 
interval is not represented in the sedimentary section, the difference in indicated depths between benthic assemblages I and II indicates that the top of the seamount had reached a depth of 1000 meters by the early Miocene. This requires an average subsidence rate of about $2.2 \mathrm{~cm} / 1000$ years, which is only slightly greater than the Paleocene shallow-water carbonate sediment accumulation rate of $1.8 \mathrm{~cm} / 1000$ years. The data indicate that subsidence since the early Miocene has been more nearly $4.4 \mathrm{~cm} / 1000$ years. If the benthic assemblages are providing reliable estimates of the paleodepths of Suiko, then it appears that the rate of subsidence may have increased as the seamount aged. This is contrary to what one would expect were the subsidence entirely a result of crustal aging (Sclater et al., 1971; Parsons and Sclater, 1977) and rethickening of the lithosphere with distance from a hot spot (Detrick and Crough, 1978).

Finally, several aspects of the Quaternary sedimentation on the seamounts deserve mention. First, the uppermost three meters or so of sediment from Site 431 on Yōmei Seamount consists predominantly ( 80 to $90 \%$ ) of fragments of a ferromanganese crust or pavement. Similar material was found in the upper part of the core from Site 430 on Ojjin, but in lesser quantities. The ferromanganese pavement material is similar in composition to manganese nodules and pavements found elsewhere in the Pacific (Karpoff et al., this volume). We do not know the extent of this pavement, but if it is common on the Emperor Seamounts, then there might be potential ferromanganese ore at relatively shallow depths. Second, ice-rafted glacial pebbles are common in the uppermost part of the cores from Suiko and Yomei, but are absent in the cores from Nintoku and Öjin. This places the ice-rafting limit in the northwest Pacific at longitude $170^{\circ} \mathrm{E}$ between $41^{\circ} 20^{\prime} \mathrm{N}$ and $42^{\circ} 25^{\prime} \mathrm{N}$ (Figure 1), which is consistent with the limits determined by Conolly and Ewing (1970), on the basis of their analysis of northwest Pacific piston cores.

\section{REFERENCES}

Anderson, D. L., 1975. Chemical plumes in the mantle, Geol. Soc. Amer. Bull., v. 86, pp. 1593-1600.

Bargar, K. E. and Jackson, E. D., 1974. Calculated volumes of individual shield volcanoes along the Hawaiian-Emperor chain, Jour. Research U. S. Geol. Survey, v. 2, pp. 545-550.

Beeson, M. H., 1976. Petrology, mineralogy and geochemistry of the lavas of East Molokai Volcano, Hawaii, U. S. Geol. Surv. Prof. Paper 961, 53 pp.

Betz, F., Jr. and Hess, H. H., 1942. The floor of the North Pacific Ocean, Geog. Rev., v. 32, pp. 99-116.

Bezrukov, P. L. and Udincev, G. B., 1955. The northern end of the Hawaiian suboceanic ridge, Dok. Akad. Nauk., v. 103, no. 6, pp. 1077-1080.

Blakely R. J. and Christiansen, R. L., 1978. The magnetization of Mount Shasta and implications for virtual geomagnetic poles determined from seamounts, Jour. Geophys. Res., v. 83, pp. 5971-5978.

Bonhommet, N., Beeson, M. H., and Dalrymple, G. B., 1977. A contribution to the geochronology and petrology of the Island of Lanai, Hawaii, Geol. Soc. Amer. Bull., v. 88, pp. 1282-1286.
Bukry, D., 1975. Coccolith and silicoflagellate stratigraphy, northwestern Pacific Ocean, Deep Sea Drilling Project Leg 32. In Larson, R. L., Moberly, R., et al., Initial Reports of the Deep Sea Drilling Project, v. 32: Washington (U. S. Govt. Printing Office), pp. 677-701.

Byrne, T., 1979. Late Paleocene demise of the Kula-Pacific spreading center, Geology, v. 7, pp. 341-344.

Chase, C. G., 1978. Plate kinematics: the Americas, East Africa, and the rest of the world, Earth Planet Sci. Lett., v. 37, pp. $355-368$.

Christofferson, E., 1968. The relationship of sea-floor spreading in the Pacific and the origin of the Emperor Seamounts and the Hawaiian Island chain (Abs.), Amer. Geophys. Union Trans., v. 49, pp. 214.

Clague, D. A., 1974. The Hawaiian-Emperor Seamount Chain: Its Origin, Petrology and Implications for Plate Tectonics: Ph.D. thesis, University of Calif., San Diego, $319 \mathrm{pp}$.

Clague, D.A. and Beeson, M.H., in press. Trace element geochemistry of the East Molokai volcanic series, Hawaii, Am. Jour. Sci., Jackson volume.

Clague, D. A. and Dalrymple, G. B., 1973. Age of Kōkō Seamount, Emperor Seamount chain, Earth Planet. Sci. Lett., v. 17 , pp. 411-415.

Clague, D. A., Dalrymple, G. B., and Moberly, R., 1975. Petrography and $\mathrm{K}-\mathrm{Ar}$ ages of dredged volcanic rocks from the western Hawaiian Ridge and southern Emperor Seamount chain, Geol. Soc. Amer. Bull., v. 86, pp. 991-998.

Clague, D. A., Frey, F. A., and Natland, J. H., 1977. Petrogenesis of the Honolulu Volcanic Series: constraints based on trace element data, EOS, v. 58, p. 533.

Clague, D. A. and Jarrard, R. D., 1973. Tertiary Pacific plate motion deduced from the Hawaiian-Emperor chain, Geol. Soc. Amer. Bull., v. 84, pp. 1135-1154.

Cole, W. S., 1969. Larger foraminifera from deep drill holes on Midway Atoll, U. S. Geol. Survey Prof. Paper 680-C, $15 \mathrm{pp}$.

Conolly, J. R. and Ewing, M., 1970. Ice-rafted detritus in Northwest Pacific deep-sea sediments, Geol. Soc. America Mem. 126, pp. 219-231.

Creager, J.S., Scholl, D.W., 1973. Geologic synthesis of Leg 19 (DSDP) results: Far North Pacific, and Aleutian Ridge, and Bering Sea. In Creager, J.S., Scholl, D.W., et al., Initial Reports of the Deep Sea Drilling Project, v. 19: Washington (U.S. Govt. Printing Office), pp. 897-913.

Dalrymple, G. B., 1971. Potassium-argon ages from the Pololu Volcanic Series, Kohala Volcano, Hawaii, Geol. Soc. America Bull., v. 82, pp. 1997-2000.

Dalrymple, G. B. and Clague, D. A., 1976. Age of the Hawaiian-Emperor bend, Earth Planet. Sci. Lett., v. 31, pp. 313-329.

Dalrymple, G. B., Clague, D. A., and Lanphere, M. A., 1977. Revised age for Midway volcano, Hawaiian Volcanic chain, Earth Planet. Sci. Lett., v. 37, pp. 107-116.

Dalrymple, G. B., Lanphere, M. A., and Jackson, E. D., 1974. Contributions to the petrography and geochronology of volcanic rocks from the leeward Hawaiian Islands, Geol. Soc. America Bull., v. 85, pp. 727-738.

Dana, J. D., 1849. Geology, Volume 10 of United States Exploring Expedition During the Years 1838-39, 1840, 1841, 1842: Philadelphia (C. Sherman, Co.), 756 pp.

1890. Characteristics of volcanoes. New York (Dodd, Mead and Co.), 399 pp.

Davies, D. and Sheppard, R. M., 1972. Lateral heterogeneity in the earth's mantle, Nature, v. 239, pp. 318-323.

Davies, T. A., Clague, D. A., and Wilde, P., 1971. Preliminary report on Leg VII of Aries expedition: Geological in- 
vestigations in the western North Pacific, SIO Reference Series No. 71-27.

Davies, T. A., Wilde, P., and Clague, D. A., 1972. Kōkō Seamount: A major guyot at the southern end of the Emperor Seamounts, Marine Geol. v. 13, pp. 311-321.

Detrick, R. S. and Crough, S. T., 1978. Island subsidence, hot spots, and lithospheric thinning, Jour. Geophs. Res., v. 83, pp. 1236-1244.

Doell, R. R. and Dalrymple, G. B., 1973. Potassium-argon ages and paleomagnetism of the Waianae and Koolau Volcanic Series, Oahu, Hawaii, Geol. Soc. America Bull., v. 84 , pp. $1217-1242$.

Dietz, R. S., 1954. Marine geology of Northwestern Pacific: Description of Japanese Bathymetric Chart 6901, Geol. Soc. America Bull., v. 65, pp. 1199-1224.

Funkhouser, F. G., Barnes, I. L., and Naughton, J. J., 1968. The determination of a series of ages of Hawaiian volcanoes by the potassium-argon method, Pacific Science, v. 22, pp. 369-372.

Green, A. G., 1975. On the postulated Hawaiian plume with emphasis on the limitations of seismic arrays for detecting deep mantle structure, Jour. Geophys. Res., v. 80, pp. 4028-4036.

Green, D. H., 1971. Composition of basaltic magmas as indicators of conditions of origin: application to oceanic volcanism, Royal Soc. London Philos. Trans. Ser. A., v. 268, pp. 707-725.

Greene, H. G., Dalrymple, G. B., and Clague, D. A., 1978. Evidence for northward movement of the Emperor Seamounts, Geology, v. 6, pp. 70-74.

Grommé, S. and Vine, F. J., 1972. Paleomagnetism of Midway Atoll lavas and northward movement of the Pacific plate, Earth Planet. Sci. Lett., v. 17, pp. 159-168.

Hammond, S. R., Epp, D., and Theyer, F., 1979. Neogene relative motion between the Pacific plate, the mantle, and the earth's spin axis, Nature, v. 278, pp. 309-312.

Handschumacher, D., 1973. Formation of the Emperor Seamount chain, Nature, v. 244, pp. 150-152.

Heckel, P. H., 1974. Carbonate buildups in the geologic record: A review. In Laporte, L. F., (Ed.), Reefs in Time and Space: Soc. Econ. Paleontologists and Mineralogists Spec. Publ. 18, pp. $90-154$.

Hilde, T. W. C., Isezaki, N., and Wageman, J. M., 1976. Mesozoic sea-floor spreading in the North Pacific. In Sutton, G. H., Manghnani, M. H., and Moberly, R., (Eds.), The Geophysics of the Pacific Ocean Basin and its Margins: American Geophys. Union Geophysical Monograph 19 (Woolard volume) pp. 205-226.

Hofmann, A. W. and Hart, S. R., 1978. An assessment of local and regional isotopic equilibrium in the mantle, Earth Planet. Sci. Lett., v. 38, pp. 44-62.

Hsü, K. J. and Schlanger, S. O., 1968. Thermal History of the upper mantle and its relations to crustal history in the Pacific basin, Proc. 23d. Internat. Geol. Cong. (Prague), v. 1, pp. 91-105.

Jackson, E. D., 1976. Linear volcanic chains on the Pacific plate. In Sutton, G. H., Maghnani, M. H., and Moberly, Ralph, (Eds.), Geophysics of the Pacific basin and Its Margin: American Geophys. Union Geophysical Monograph 19, pp. 319-335.

Jackson, E. D. and Shaw, H. R., 1975. Stress fields in central portions of the Pacific plate delineated in time by linear volcanic chains, Jour. Geophys. Res., v. 80, pp. 18611874.

Jackson, E. D., Shaw, H. R., and Bargar, K. E., 1975. Calculated geochronology and stress field orientations along the Hawaiian chain, Earth Planet. Sci. Lett., v. 26, pp. 145-155.
Jackson, E. D., Silver, E. A., and Dalrymple, G. B., 1972. Hawaiian-Emperor chain and its relation to Cenozoic circum-Pacific tectonics, Geol. Soc. America Bull., v. 83, pp. 601-618.

Jackson, E. D. and Wright, T. L., 1970. Xenoliths in the Honolulu Volcanic Series, Jour. Petrology, v.11, pp. 405-430.

Jarrard, R. D. and Clague, D. A., 1977. Implications of Pacific island and seamount ages for the origin of volcanic chains, Rev. Geophys. and Space Phys., v. 15, pp. 57-76.

Jurdy, D. M. and Van der Voo, R., 1975. True polar wander since the Early Cretaceous, Science, v. 187, pp. 1193-1196.

Kanasewich, E. R., Ellis, R. M., Chapman, C. H., and Gutowski, P. R., 1972. Teleseismic array evidence for inhomogeneities in the lower mantle and the origin of the Hawaiian Islands, Nature Physical Science, v. 239, pp. 99-100.

1973. Seismic array evidence of a core boundary source for the Hawaiian linear volcanic chain, Jour. Geophys. Res., v. 78, pp. 1361-1371.

Kodama, K., Uyeda, S., and Isezaki, N., 1978. Paleomagnetism of Suiko Seamount, Emperor Seamount chain, Geophys. Res. Lett., v. 5, pp. 165-168.

Ladd, H. S., Tracy, J. I., Jr., and Gross, M. G., 1970. Deep drilling on Midway Atoll, U.S. Geol. Survey Prof. Paper 680- $A, 22 \mathrm{pp}$.

Lanphere, M. A. and Dalrymple, G. B., 1980. Age and strontium isotopic composition of the Honolulu Volcanic Series, Oahu, Hawaii, American Jour. Sci. (Jackson volume).

Larson, R. L., Moberly, R., et al., 1975. Initial Reports of the Deep Sea Drilling Project, v. 32: Washington (U.S. Govt. Printing Office).

Leeman, W. P., Budahn, J. R., Gerlach, D. C., Smith, D. R., and Powell, B. N., in press. Origin of Hawaiian tholeiites: trace element constraints, American Jour. Sci., Jackson volume.

Macdonald, G. A., 1968. Composition and origin of Hawaiian lavas, Geol. Soc. Amer. Mem. 116, pp. 477-522. 1969. Petrology of the basalt cores from Midway Atoll, Geol. Survey Prof. Paper 680-B, pp. B1-B10.

1976. Some highlights in the development of volcanology in the Pacific area. In Sutton, G. H., Manghnani, M. H., and Moberly, R. (Eds.), The Geophysics of the Pacific Ocean Basin and its Margins: American Geophys. Union Geophysical Monograph 19 (Woolard volume), pp. 309-317.

Macdonald, G. A. and Katsura, T., 1964. Chemical composition of Hawaiian lavas, Jour. Petrology, v. 5, pp. 82-133.

Marshall, M., 1978. The magnetic properties of some DSDP basalts from the North Pacific and inferences for Pacific plate tectonics, Jour. Geophys. Res., v. 83, pp. 289-308.

Matter, A. and Gardner, J. V., 1975. Carbonate diagenesis at Site 308, Kōkō Guyot. In Larson, R. L., Moberly, R., et al., Initial Reports of the Deep Sea Drilling Project, v. 32: Washington (U.S. Govt. Printing Office), pp. 521-535.

McDougall, I., 1963. Potassium-argon ages from western Oahu, Hawaii, Nature, v. 197, pp. 344-345.

1964. Potassium-argon ages from lavas of the Hawaiian Islands, Geol. Soc. America Bull., v. 75, pp. 107-128.

1969. Potassium-argon ages on lavas of Kohala Volcano, Hawaii, Geol. Soc. America Bull., v. 80, pp. 2597-2600.

1971. Volcanic island chains and sea-floor spreading, Nature Phys. Sci., v. 231, pp. 141-144.

McDougall, I. and Swanson, D. A., 1972. Potassium-argon ages of lavas from the Hawi and Pololu Volcanic Series, 
Kohala Volcano, Hawaii, Geol. Soc. America Bull., v. 83, pp. 3731-3738.

McKenzie, D.,(in press). Finite deformation during fluid flow, Geophys. Jour. Roy. Astr. Soc.

McNutt, Marcia and Menard, H. W., 1978. Lithospheric flexure and uplifted atolls, Jour. Geophys. Res., v. 83, pp. $1206-1212$.

Menard, H. W., 1973. Depth anomalies and the bobbing motion of drifting islands, Jour. Geophys. Res., v. 78, pp. 5128-5137.

Minster, J. B. and Jordon, T. H., 1978. Present-day plate motions, Jour. Geophys. Res., v. 83, pp. 5331-5354.

Minster, J. B., Jordan, T. H., Molnar, P., and Haines, E., 1974. Numerical modeling of instantaneous plate tectonics, Geophys. Jour. Roy. Astron. Soc., v. 36, pp. 541-546.

Molnar, P. and Atwater, T., 1973. Relative motion of hotspots in the mantle, Nature, v. 246, pp. 288.

Moore, J. G., 1965. Petrology of deep-sea basalt near Hawaii, American Jour. Sci., v. 263, pp. 40-52.

Morgan, W. J., 1972a. Deep mantle convection plumes and plate motions, Am. Assoc. Petroleum Geol. Bull., v. 56, (2), pp. 203-213.

1972b. Plate motions and deep mantle convection. In Shagam, R. (Ed.), Studies in Earth and Space Sciences (Hess volume): Geol. Soc. America Mem. 32, pp. 265-282.

Muromtsev, A. M., 1958. The Principal Hydrologic Features of the Pacific Ocean. Leningrad (Gidrometeorologicheskoe Izdatel'stvo) (Transl. from Russian, Jerusalem, 1963, Israel Prog. Sci. Trans.), 417 pp.

Ozima, M., Kaneoka, I., and Aramaki, S., 1970. K-Ar ages of submarine basalts dredged from seamounts in the western Pacific area and discussion of oceanic crust, Earth Planet. Sci. Lett., v. 8, pp. 237-249.

Parsons, B. and Sclater, J. G., 1977. An analysis of the variation of ocean floor bathymetry and heat flow with age, Jour. Geophys. Res., v. 82, pp. 803-827.

Porter, S. C., Stuiver, M., and Yang, I. C., 1977. Chronology of Hawaiian glaciations, Science, v. 195, pp. 61-63.

Purdy, E. G., 1974. Reef configurations: Cause and effect. In Laporte, L. F. (Ed.), Reefs in Time and Space -Selected Examples from the Recent and Ancient: Soc. Eco. Paleo. Mine. Spec. Pub., No. 18, pp. 9-76.

Richter, F. M. and Ribe, N. M., in press. On the importance of advection in determining the local isotopic composition of the mantle, Earth Planet. Sci. Lett.

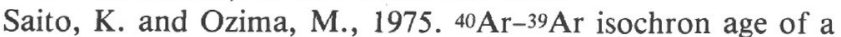
mugearite dredged from Suiko seamount in the Emperor chain, Rock Magnetism and Paleogeophys., v. 3, pp. 81-84. 1977.40Ar-39Ar geochronological studies on submarine rocks from the western Pacific area, Earth Planet. Sci. Lett., v. 33, pp. 353-369.

Savin, S. M., 1977. The history of the earth's surface temperature during the past 100 million years, Ann. Rev. Earth Planet. Sci., v. 5, pp. 319-355.

Savin, S. M., Douglas, R. G., and Stehli, F. G., 1975. Tertiary marine paleotemperatures, Geol. Soc. America Bull., v. 86, pp. 1499-1510.

Schlanger, S. O. and Douglas, R. G., 1974. The pelagic oozechalk-limestone transition and its implications for marine stratigraphy. In Hsü, K. J. and Jenkyns, H. (Eds.), Pelagic Sediments on Land and Under the Sea: Internat. Assn. Sedimentol. Spec. Publ. 1, pp. 117-148.

Schlanger, S. O. and Gillett, G. W., 1976. A geological perspective of the upland biota of Laysan atoll, Hawaiian Island, Bio. Jour. Linn. Soc., v. 8, pp. 205-216.
Schlanger, S. O. and Konishi, K., 1975. The geographic boundary between the Coral-Algal and the BryozoanAlgal limestone facies: A paleolatitude indicator. IX International Congress of Sedimentology, Nice, Theme 1, Sedimentologic Indicators, pp. 187-190.

Scholl, D. W. and Creager, J. S., 1973. Geologic synthesis of Leg 19 (DSDP) results; Far North Pacific, Aleutian Ridge, and Bering Sea. In Creager, J. S., Scholl, D. W., et al. , Initial Reports of the Deep Sea Drilling Project, v. 19: Washington (U.S. Govt. Printing Office), pp. 897-913.

Scientific Staff, 1978. Drilling confirms hot-spot origins, Geotimes, v. 32, pp. 23-26.

Sclater, J. G., Anderson, R. N., and Bell, M. L., 1971. The elevation of ridges and the evolution of the central eastern Pacific, Jour. Geophys. Res., v. 76, pp. 7888-7915.

Shaw, H. R., 1973. Mantle convection and volcanic periodicity in the Pacific: Evidence from Hawaii, Geol. Soc. America Bull., v. 84, pp. 1505-1526.

Shaw, H. R. and Jackson, E. D., 1973. Linear island chains in the Pacific: Result of thermal plumes or gravitational anchors?, Jour. Geophys. Res., v. 78, pp. 8634-8652.

Shaw, H. R., Jackson, E. D., and Bargar, K. E., in press. Volcanic periodicity along the Hawaiian-Emperor chain, American Jour. Sci. (Jackson volume).

Stearns, H. T., 1946. Geology of the Hawaiian Islands, $\mathrm{Ha}$ waii Div. Hydrography Bull., v. 8, 106 pp.

1966. Geology of the State of Hawaii. Palo Alto (Pacific Books), 226 pp.

1974. Submerged shorelines and shelves in the Hawaiian Islands, and a revision of some of the eustatic emerged shorelines, Geol. Soc. America Bull., v. 85, pp. 795-804.

1978. Quaternary shorelines in the Hawaiian Islands, Bernice P. Bishop Museum Bull., v. 237, 57 pp.

Steiger, R. H. and Jäger, E., 1977. Subcommission on Geochronology: Convention on the use of decay constants in geo- and cosmochronology, Earth Planet. Sci. Lett., v. 36, pp. 359-362.

Tayama, R., 1952. On the near-Japan bathymetric chart (introduction to the submarine geography of the northwest Pacific), Hydrographic Magazine, no. 32, pp. 160-167 and 201 (in Japanese).

Todd, R. and Low, D., 1970. Smaller foraminifera from Midway drill holes, U.S. Geol. Survey Prof. Paper 680-E, $46 \mathrm{pp}$.

Vaughan, T. W. and Wells, J. W., 1943. Revision of the suborders, families, and genera of the Scleractinia, Geol. Soc. America Spec. Paper 44, 363 pp.

Wilson, J. T., 1963a. A possible origin of the Hawaiian Islands, Canadian Jour. Physics, v. 41, pp. 863-870.

Wilson, J. T., 1963b. Evidence from islands on the spreading of the ocean floor, Nature, v. 197, pp. 536-538.

Winterer, E. L., 1973. Sedimentary facies and plate tectonics of the equatorial Pacific, American Assoc. Petroleum Geol. Bull., v. 57, pp. 265-282.

Worsley, T. R., 1973. Calcareous nannofossils, Leg 19 (DSDP). In Creager, J. S., Scholl, D. W., et al., Initial Reports of the Deep Sea Drilling Project, v. 19: Washington (U.S. Govt. Printing Office), pp. 741-750.

Wright, T. L., 1971. Chemistry of Kilauea and Mauna Loa lavas in space and time, U.S. Geol. Survey Prof. Paper 735, $40 \mathrm{pp}$.

Wright, T. L. and Fiske, R. S., 1971. Origin of the differentiated and hybrid lavas of Kilauea volcano, Hawaii, Jour. Petrol., v. 12, pp. 1-65. 